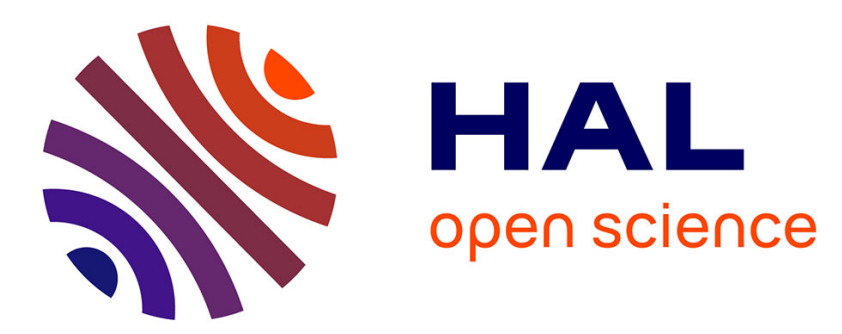

\title{
Inhaled corticosteroids as combination therapy with $\beta$-adrenergic agonists in airways disease: present and future
}

\author{
Kian Fan Chung, Gaetano Caramori, Ian M. Adcock
}

\section{To cite this version:}

Kian Fan Chung, Gaetano Caramori, Ian M. Adcock. Inhaled corticosteroids as combination therapy with $\beta$-adrenergic agonists in airways disease: present and future. European Journal of Clinical Pharmacology, 2009, 65 (9), pp.853-871. 10.1007/s00228-009-0682-z . hal-00534974

\author{
HAL Id: hal-00534974 \\ https://hal.science/hal-00534974
}

Submitted on 11 Nov 2010

HAL is a multi-disciplinary open access archive for the deposit and dissemination of scientific research documents, whether they are published or not. The documents may come from teaching and research institutions in France or abroad, or from public or private research centers.
L'archive ouverte pluridisciplinaire HAL, est destinée au dépôt et à la diffusion de documents scientifiques de niveau recherche, publiés ou non, émanant des établissements d'enseignement et de recherche français ou étrangers, des laboratoires publics ou privés. 


\title{
Inhaled corticosteroids as combination therapy with $\beta$-adrenergic agonists in airways disease: present and future
}

\author{
Kian Fan Chung • Gaetano Caramori • Ian M. Adcock
}

Received: 15 January 2009 /Revised: 27 May 2009 / Accepted: 2 June 2009 /Published online: 26 June 2009

(C) Springer-Verlag 2009

\begin{abstract}
Inhaled corticosteroid (ICS) therapy in combination with long-acting $\beta$-adrenergic agonists represents the most important treatment for chronic airways diseases such as asthma and chronic obstructive pulmonary disease (COPD). ICS therapy forms the basis for treatment of asthma of all severities, improving asthma control, lung function and preventing exacerbations of disease. Use of ICS has also been established in the treatment of COPD, particularly symptomatic patients, who experience useful gains in quality of life, likely from an improvement in symptoms such as breathlessness and in reduction in exacerbations, and an attenuation of the yearly rate of deterioration in lung function. The addition of long-acting $\beta$-agonist (LABA) therapy with ICS increases the efficacy of ICS effects in moderate-to-severe asthma. Thus, a $800 \mu \mathrm{g}$ daily dose of the ICS budesonide reduced severe exacerbation rates by $49 \%$ compared to a low dose of $200 \mu \mathrm{g}$ daily, and addition of the LABA formoterol to budesonide $(800 \mu \mathrm{g})$ led to a $63 \%$ reduction. In COPD, the effects of ICS are less prominent but there are beneficial effects on the decline in $\mathrm{FEV}_{1}$ and the rate of exacerbations. A reduction in the rate of decline in $\mathrm{FEV}_{1}$ of $16 \mathrm{ml} /$ year with a $25 \%$ reduction in exacerbation rate has been reported with the salmeterol and fluticasone combination. A nonsignificant $17.5 \%$ reduction in all-cause mortality rate with ICS and LABA is reported. Chronic inflammation is a
\end{abstract}

K. F. Chung $(\bowtie) \cdot$ G. Caramori $\cdot$ I. M. Adcock

Airway Disease Section, National Heart and Lung Institute,

Imperial College London,

Dovehouse Street,

London SW3 6LY, UK

e-mail: f.chung@imperial.ac.uk

G. Caramori

Department of Asthma and COPD, University of Ferrara,

Ferrara, Italy feature of both asthma and COPD, although there are site and characteristic differences. ICS targets this inflammation although this effect of ICS is less effective in patients with severe asthma and with COPD; however, addition of LABA may potentiate the anti-inflammatory effects of ICS. An important consideration is the presence of corticosteroid insensitivity in these patients. Currently available ICS have variably potent binding activities to specific glucocorticoid receptors, leading to inhibition of gene expression by either binding to DNA and inducing anti-inflammatory genes or by repressing the induction of pro-inflammatory mediators. Local side effects of ICS include oral candidiasis, hoarseness and dysphonia, while systemic side effects, such as easy bruising and reduction in growth velocity or bone mineral densitometry, are usually restricted to doses above maximally recommended doses. Use of LABA alone in patients with asthma increases the risk of asthma-related events including deaths, but this is less observed with the combination of ICS and LABA. Therefore, use of LABA alone is not recommended for asthma therapy. Future progress in ICS development will be characterised by the introduction of ICS with greater efficacy with a limited side-effect profile, and by longer-acting ICS that can be used in combination with oncedaily LABAs. Other agents that could improve the efficacy of corticosteroids or reverse corticosteroid insensitivity may be added to ICS. ICS in combination with LABAs will continue to remain the main focus of treatment of airways diseases.

Keywords Asthma . Chronic obstructive pulmonary disease . Corticosteroids $\cdot$ Beta-adrenergic agonists $\cdot$ Inflammation

\section{Introduction}

Asthma therapy was revolutionised in the early 1970s by the introduction of inhaled corticosteroid (ICS) therapy, 
which has subsequently proved to be the most effective anti-inflammatory treatment for asthma control. ICS therapy was later introduced for the treatment of COPD with benefits particularly in more advanced disease although its effectiveness is less evident than its effect in asthma. The use of ICS alone as the gold standard in airways disease has been superseded by the discovery that, in combination with long-acting $\beta$-agonists (LABA), the effects of ICS are improved. The combination of ICS and LABA will likely remain the cornerstone of treatment for the next decades. Improved understanding of the molecular mechanisms of ICS will lead to the development of new CS molecules that could provide even greater efficacy with a reduced risk of systemic side-effects. Further, understanding the mechanisms underlying relative CS insensitivity in asthma and COPD may lead to novel combinations that will restore CS sensitivity in these patients. In this review, we will examine the mechanisms of action, the pharmacokinetics and the clinical effects of ICS in both asthma and COPD.

\section{Molecular mechanisms of corticosteroids}

Corticosteroids belong to the family of 21-carbon steroid nuclear hormones [1] and act by binding to the ubiquitously expressed glucocorticoid receptor (GR) which is predominantly localised to the cytoplasm. Corticosteroids freely diffuse from the circulation across the cell membrane into cells and bind to cytoplasmic GR inducing a conformational change in the receptor, loss of its chaperone proteins and its nuclear localisation. GR is a phosphoprotein [2] and as with many other transcription factors the ability of GR to associate with the importin machinery is regulated by its phosphorylation status [3].

Classically, two GR proteins combine together and bind to DNA at consensus glucocorticoid response elements (GREs) in the regulatory regions of corticosteroidresponsive genes to induce anti-inflammatory or some innate immune genes [3]. Once DNA-bound, the active GR dimer recruits a number of transcriptional coactivator proteins, including SRC-1 and cyclic AMP response elementbinding protein (CBP), and basic transcription factors to form a pre-initiation complex. These co-activators have intrinsic histone acetyltransferase (HAT) activity which tags $\mathrm{N}$-terminal lysine residues in the local histones (H3 and $\mathrm{H} 4$ ) allowing recruitment of chromatin remodelling complexes including the SWI/SNF complex [3].

Histone acetylation induced by transcriptional coactivators, such as CBP and p300/CBP-associated factor [4], is associated with increased gene transcription whereas, in contrast, hypoacetylation induced by histone deacetylases (HDACs) is correlated with reduced transcription or gene silencing [4]. GRs can bind to DNA as heterodimers with many other transcription factors, such as members of the signal transducer and activator of transcription (STAT) family, the ETS transcription factors and the vitamin D3 receptor $[5,6]$ leading to the recruitment of distinct coactivator (e.g. GRIP-1) or corepressor (e.g. RIP140 or HDAC) complexes [7, 8].

Increased transcription of anti-inflammatory genes that are relevant to airways diseases such as annexin 1, IL-10 and glucocorticoid-inducible leucine zipper (GILZ) may account for the anti-inflammatory effects of corticosteroids. However, the major anti-inflammatory effects of glucocorticoids are likely to be through repression of inflammatory and immune genes since most GR-repressible genes do not posses negative GREs. The activated monomeric form of GR can interact directly with other transcription factors, particularly NF-KB and activator protein 1 (AP-1), which mediate the expression of inflammatory genes. Maximum inflammatory gene expression probably requires that a number of transcription factors act together in a coordinated manner, and glucocorticoids, by targeting several transcription factors, might have greater effects than if only a single factor was targeted. The precise mechanism for this repression may include binding and recruiting nuclear receptor corepressors such as NCoR and HDACs, direct repression of coactivator complexes, or effects on RNA polymerase II phosphorylation [7, 8]. For example, in primary airway smooth-muscle cells, fluticasone attenuates TNF- $\alpha$-induced histone $\mathrm{H} 4$ acetylation leading to a reduction in p65 association with the native CCL11 promoter and suppression of CCL11 expression [9]. In addition, glucocorticoids might play a role in repressing the action of MAPKs, such as the extracellular signal-regulated kinase (ERK), p38 MAPK, and c-Jun N-terminal kinase (JNK) $[2,7,8]$. These actions are mutually inhibitory and, in the case of $\mathrm{p} 38$ and JNK, may relate to induction of the dual-specificity MAPK phosphatase 1 (MKP-1), which thereby attenuates MAPK activation [10]. Importantly, p38 MAPK-mediated GR phosphorylation can attenuate GR function $[7,11]$.

Glucocorticoids can also regulate the stability of proinflammatory gene mRNAs which contain adenylateuridylate-rich elements (AREs) within their 3' untranslated regions $[10,12]$. ARE-binding proteins such tristetrapolin (TTP), which promotes mRNA decay, and Hu antigen R (HuR) family members, which are associated with mRNA stability, interact with AREs to form messenger ribonucleoprotein complexes, which modulate mRNA decay [12]. HuR binding to AREs is dependent on p38 MAPK $[10,12]$, and dexamethasone may control the levels of HuR and TTP, thereby reducing the levels of inflammatory gene mRNAs such as COX-2 and CCL11 through a p38 MAPK-mediated pathway subsequent to induction of MKP-1 [10]. 
The traditional genomic theory of steroid action, whether directly interacting with DNA or involving cross-talk with other transcription factors, does not fully explain the rapid effects of corticosteroids such as their blanching effects on skin, representing an acute vasoconstrictor effect, and in the airways as an acute reduction in bronchial blood flow with ICS [13]. Alternative explanations have been invoked to explain this rapid effect. GR is associated with a number of kinases and phosphatases within the inactive GR-hsp90 complex and these are released upon ligand binding [7, 8]. It is possible that these might account for the rapid changes in cell function induced in some cells by glucocorticoids. In addition, a distinct membrane-localised GR has been described. These receptors have distinctive hormonebinding properties compared with the well-characterized cytoplasmic GR and are probably linked to a number of intracellular signaling pathways acting through G-proteincoupled receptors and a number of kinase pathways. This mechanism may account for the change in bronchial blood flow induced by inhaled corticosteroids. In addition, the classical receptor is associated with a number of kinases and phosphatases within the inactive GR-hsp90 complex $[14,15]$. These enzymes are released on hormone binding and might also account for the rapid induction of tyrosine kinases seen in some cell types by glucocorticoids.

\section{Anti-inflammatory effects of ICS in asthma}

\section{Effects on inflammation}

ICS are effective anti-asthma agents that can reverse the specific chronic airway inflammation present in asthma [16-19]. ICS reduce the number of mast cells, macrophages, T-lymphocytes and eosinophils in the sputum, bronchoalveolar lavage and bronchial wall [20, 21]. Furthermore, ICS reverse the shedding of epithelial cells, goblet-cell hyperplasia and basement-membrane thickening characteristic of the airway mucosa of patients with asthma [18, 22]. ICS may reduce the increased airway wall vascularity [23] and also the increased airway mucosal blood flow present in asthmatic patients [24]. ICS has also been reported to reduce the increased thickness of the subbasement membrane representing increased deposition of the extracellular matrix $[22,25]$, but other studies do not support this. The inflammatory component of asthmatic airways that is most responsive to glucocorticoid treatment appears to be the eosinophilic inflammation. Importantly, in patients with persistent asthma, well- controlled tapering of inhaled glucocorticoids induces an exacerbation within a few months that is associated with a reversible increase of eosinophilic airway inflammation [26, 27]. These observations indicate that glucocorticoids suppress the inflamma- tory response only whilst being actively taken and the effects wear off with time.

\section{Cellular effects}

Glucocorticoids may have direct inhibitory effects on many of the cells involved in airway inflammation in asthma, including macrophages, T-lymphocytes, eosinophils, mast cells, and airway smooth-muscle and epithelial cells [28, 29]. In culture, glucocorticoids decrease cytokine-mediated survival of eosinophils by stimulating apoptosis [30]. This process may explain the reduction in the number of eosinophils in the circulation and airways of patients with asthma during glucocorticoid therapy [18, 20]. Glucocorticoids may not inhibit the release of mediators from mast cells $[31,32]$, but they reduce the number of mast cells within the airway [33]. In addition, ICS reduce the expression of the activation markers CD25 and HLA-DR in both CD4+ and CD8+ T-cell subsets in peripheral blood and bronchoalveolar lavage fluid of patients with asthma $[34,35]$. Part of the anti-inflammatory activity of glucocorticoids in asthma may also involve a reduction in macrophage eicosanoid (leukotriene $\mathrm{B}_{4}$ and thromboxane $\mathrm{B}_{2}$ ) and cytokine (i.e. interleukin $1 \beta$ ) synthesis [36, 37]. In contrast, glucocorticoids either have no effect on, or may even augment, neutrophil-mediated inflammation [38]. Glucocorticoids enhance neutrophil function through increased leukotriene and superoxide production, as well as inhibition of apoptosis [39, 40].

\section{Anti-mediator effects}

In vivo and in vitro studies suggest that glucocorticoids produce minimal suppression of leukotriene production and in some cases may enhance their production [38]. However, levels of exhaled nitric oxide, a marker of asthmatic airway inflammation, are consistently decreased by treatment with ICS [21, 41]. Glucocorticoids also block the generation of several pro-inflammatory cytokines and chemokines, including interleukin (IL)-1 $\beta$, IL-4, IL-5, IL-8, granulocytemacrophage colony stimulating factor (GM-CSF), tumour necrosis factor $\alpha$ (TNF- $\alpha)$, RANTES and macrophage inflammatory protein-1 $\alpha$ (MIP-1 $\alpha)$ [42] in the asthmatic lung. Inhibitory effects of cytokine and chemokine release have also been demonstrated in airway smooth-muscle cells [43]. In contrast, glucocorticoids can increase the production of the anti-inflammatory cytokine IL-10 from BAL alveolar macrophages [44], but not of IL-1R $\alpha$ in the bronchial mucosa of asthmatic patients [45].

Airway hyperresponsiveness (AHR) may be directly caused by inflammatory mechanisms [46]. ICS consistently lessen AHR in asthma [47-49] and long-term treatment with glucocorticoids reduced airway responsiveness to both 
direct and indirect challenges including histamine, cholinergic agonists, allergens (affecting both early and late responses), exercise, fog, cold air, bradykinin, adenosine and irritants such as sulfur dioxide and metabisulfites [50, 51]. ICS also limits the maximum narrowing of the airway in response to a spasmogen [52]. The reduction in airway hyperresponsiveness may not be maximal until treatment has been given for several months, although improvements may occur fairly quickly within a few hours. The magnitude of the reduction differs, but often airway responsiveness remains abnormally increased [50]. When therapy is discontinued, airway responsiveness usually returns to pretreatment levels [53-55].

\section{Anti-inflammatory effects of ICS in COPD}

COPD has been increasingly recognized as a chronic inflammatory disease of the lower airways, which is enhanced during exacerbations [56]. The GOLD guidelines now define COPD as a preventable and treatable disease with some significant extra-pulmonary effects that may contribute to its severity [57]. The airflow limitation is usually progressive and associated with an inflammatory response of the lung to noxious particles and gases. The pathological hallmarks of COPD are destruction of the lung parenchyma (pulmonary emphysema), inflammation of the peripheral airways (respiratory bronchiolitis) and inflammation of the central airways [58]. The inflammation in COPD occurs in the central and peripheral airways (bronchioles) and lung parenchyma, and there is a marked increase in macrophages and neutrophils in bronchoalveolar lavage fluid and induced sputum [59]. Patients with COPD have infiltration of $\mathrm{T}$ cells (with an increased ratio between CD8+ and CD4+ T cells), macrophages and an increased number of neutrophils within the airways mucosa and lung parenchyma [58]. The bronchioles are obstructed by fibrosis and infiltrated with macrophages and T lymphocytes. In contrast to the situation with asthma, eosinophils are not prominent except in patients with concomitant asthma or in some patients during exacerbations [58]. The mechanisms underlying COPD can be diverse involving local and systemic inflammation, metabolism, immunity and tissue remodelling [60].

Overall, the effects of ICS on the inflammatory process of COPD are small, if any. A 2005 meta-analysis of the effect of ICS treatment on sputum markers in COPD indicated that there was an overall effect of ICS in reducing neutrophil and lymphocyte counts to a small extent provided they were given over a prolonged period of time of greater than 6 weeks [61]. More recent studies of 6-month duration with budesonide showed no effect on sputum neutrophil count, although sputum eosinophil counts were reduced [62]; indeed, the presence of eosinophilic inflammation in COPD has been proposed as a marker of clinical responsiveness to ICS [63, 64]. A biopsy study showed that fluticasone treatment for 3 months had no effect on the number of CD8+, CD68+ and neutrophils, although $\mathrm{CD} 8 / \mathrm{CD} 4$ ratio in epithelium and subepithelial mast cells was reduced [65]. A separate report of the same study reported an increase in neutrophils after fluticasone treatment [66]. The combination of fluticasone and salmeterol caused a reduction in CD8+ T cells, CD45+ cells and $\mathrm{TNF} \alpha+$ and IFN $\gamma+$ cells in the submucosa, and a reduction in differential neutrophil count and absolute eosinophil cpount in induced sputum. These anti-inflammatory effects were accompanied by improvements in pre-bronchodilator $\mathrm{FEV}_{1}$ [67]. This effect of combination therapy may represent an improvement in the anti-inflammatory effects over that of ICS alone.

There is a strong possibility that the effects of ICS in COPD may not only be to target lung inflammation but also to inhibit systemic inflammation, which may lead to beneficial effects such as a reduction in lung-function decline or deaths. Thus, ICS therapy leads to a reduction in systemic levels in inflammatory markers such as C-reactive protein or surfactant-D [68, 69].

\section{Mechanisms for the interactions between glucocorticoids and LABA}

Molecular interactions between glucocorticoids and $\beta_{2^{-}}$ adrenoceptors may underlie the clinical added benefits of combination therapy [70]. Glucocorticoids may increase the number of $\beta_{2}$-adrenoceptors and their coupling with Gs proteins, while $\beta_{2}$-agonists may induce glucocorticoid receptor (GR) nuclear translocation, activate CAAT/ enhancer binding protein $(\mathrm{C} / \mathrm{EBP}) \alpha$ together with corticosteroids, or alter GR phosphorylation [71, 72]. The combination of glucocorticoids and LABA potentiates inhibition of CXCL8 (IL-8) and CCL11 (eotaxin) release from human airway smooth-muscle cells and their proliferation and has additive effects on granulocyte-macrophage colony-stimulating factor (GM-CSF) release from epithelial cells $[73,74]$.

\section{Corticosteroid insensitivity in airways disease}

Approximately $5-10 \%$ of patients with asthma fall in the category of those suffering from severe asthma; in these patients, despite the use of maximum ICS dose, and sometimes combined with regular oral corticosteroids, their asthma remains uncontrolled with continuing asthma symptoms, exacerbations of asthma and persistent airflow 
obstruction [75-77]. Many of these patients are labelled as corticosteroid-dependent, in that reduction in either maintenance ICS or oral CS leads to a deterioration of asthma control. Studies have reported that there is persistent neutrophilic and eosinophilic inflammation [78, 79] in the airways, together with increased subbasement membrane thickness and airway smooth-muscle mass [80, 81]. There is altered expression of markers of epithelial proliferation such as an increased expression of the proliferation marker, $\mathrm{Ki} 67$, and reduced expression of $\mathrm{Bcl}-2$, a negative regulator of epithelial cell death [82]. Studies in alveolar macrophages and blood mononuclear cells from patients with severe asthma confirmed the presence of CS insensitivity, associated with an increase in p38 MAPK activity [11, 83].

In COPD, the beneficial effects of corticosteroids are very limited and airflow obstruction of COPD responds minimally to either inhaled or oral CS therapy. There is a small response of airway inflammation to ICS therapy [61]. Dexamethasone is less efficient in inhibiting the induced release of IL- 8 by IL-1 $\beta$ or cigarette smoke extracts from alveolar macrophages from COPD patients compared to non-COPD smokers [84]. HDAC2 activity is reduced in the lungs and in lung macrophages of patients with COPD, the degree of reduction being related to severity of COPD [85]; this may result in CS insensitivity through lack of repression of NF-kB-mediated gene expression [7]. Since HDAC2 is important for deacetylation of histone $\mathrm{H} 3$ [86], the increase in histone $\mathrm{H} 3$ acetylation in COPD [87] may result from a reduction in HDAC2 activity. Theophylline, which has been used for the treatment of asthma and COPD as a bronchodilator and as a potential anti-inflammatory agent, can recruit HDAC and restore CS sensitivity of macrophages in vitro $[88,89]$.

Mechanisms of corticosteroid insensitivity

In view of the presence of CS insensitivity in asthma and COPD, it is reasonable to address the potential underlying mechanisms contributing to decreased anti-inflammatory effects of corticosteroids of which several have now been identified; there may well be heterogeneity of mechanisms even within each single disease. IL-2 and IL-4, which are overexpressed in the airways of patients with CS-resistant asthma [90], together reduce GR nuclear translocation and binding affinity within the nucleus of T-cells [7]. IL-13 alone mimics this effect in monocytes [7]. These cytokines may reduce GR function via phosphorylation of GR by $\mathrm{p} 38$ MAPK, an effect blocked by a p38 MAPK inhibitor [91]. p38 MAPK is greatly activated in alveolar macrophages from severe asthmatics compared to non-severe asthma patients [1]. Similar effects are seen with JNK, ERK and JAK3 depending upon the specific stimulus driving steroid insensitivity in vitro [7]. In severe asthmatic patients, there is also a significant reduction in MKP-1 expression in alveolar macrophages after steroid exposure, correlating with increased p38 MAPK activity [11].

Increased expression of GR $\beta$ has been reported in steroidresistant patients with asthma [7]. GR $\beta$ is induced by proinflammatory cytokines and has the capacity to compete for the binding of GR $\alpha$ to GRE, thus acting as a dominantnegative inhibitor [92]. Another mechanism may be through interference with GR $\alpha$ nuclear translocation, since knockdown of GR $\beta$ in alveolar macrophages from steroidresistant asthma patients results in increased GR $\alpha$ nuclear localisation and increased steroid responsiveness [93].

Excessive activation of AP-1 has been identified as a mechanism of steroid resistance in asthma as AP-1 binds GR and thus prevents its interaction with GRE and other transcription factors [7]. AP-1, a heterodimer of Fos and Jun proteins, is increased in PBMCs and bronchial biopsies of steroid-resistant compared to steroid-sensitive asthma, with no reduction in JNK activity or c-Jun after high doses of oral steroids [94].

HDAC2 activity and expression are reduced in severe asthma and particularly in patients with COPD [85, 95]. The steroid resistance of COPD observed in lung macrophages is completely reversed by overexpressing HDAC2 to the level seen in control subjects [96]. The mechanism of HDAC2 reduction in COPD may involve oxidative stress, which is increased in most severe and steroid-resistant inflammatory diseases.

IL-10 is an important anti-inflammatory and immunoregulatory cytokine and secreted by regulatory $\mathrm{T}$ cells (Treg) in response to steroids [97]. In patients with steroidresistant asthma, there is a failure of T-helper cells to secrete IL-10, but this is restored to normal by vitamin D3 (calcitriol) in vitro [6]. Furthermore, administration of vitamin D3 to three SR asthmatics also restored the T-cell IL-10 response to steroids. Vitamin D may be an important regulator of Tregs so that low dietary intake or lack of sunlight may be contributory to reduced steroid responses in inflammatory diseases.

\section{Properties of topical ICS}

The topical corticosteroids have a very high binding affinity for the glucocorticoid receptor and a high first-pass hepatic metabolism. Many topical corticosteroids are available for asthma and include beclomethasone dipropionate (BDP), budesonide, fluticasone propionate (FP), ciclesonide, flunisonide, triamcinolone acetate and mometasone furoate (MF). Some pharmacokinetic parameters of ICS are shown in Table 1. The clinical equivalent doses divided as low, moderate and high doses are shown in Table 2. The potency of corticosteroids has been measured in vitro in terms of 
Table 1 Pharmacokinetic properties of inhaled corticosteroids ${ }^{\mathrm{a}}$

\begin{tabular}{|c|c|c|c|c|}
\hline Inhaled corticosteroid & Relative receptor binding affinity ${ }^{\mathrm{b}}$ & Oral bioavailability (\%) & Clearance $(\mathrm{L} / \mathrm{h})$ & $\mathrm{T}_{1 / 2}(\mathrm{~h})$ \\
\hline Beclomethasone propionate & 53 & $15-20$ & 150 & 0.5 \\
\hline 17-beclomethasone mono-propionate & 1,345 & 26 & 120 & 2.7 \\
\hline Budesonide & 935 & 11 & 84 & 2.8 \\
\hline Ciclesonide & 12 & $<1$ & 152 & 0.36 \\
\hline Des-ciclesonide & 1,200 & $<1$ & 228 & 3.4 \\
\hline Fluticasone propionate & 1,800 & $<1$ & $66-90$ & $7-8$ \\
\hline Mometasone furoate & 2,300 & $<1$ & 54 & 5.8 \\
\hline Triamcinolone acetate & 233 & 23 & 37 & 2.0 \\
\hline
\end{tabular}

a Adapted from [100]

${ }^{\mathrm{b}}$ Receptor binding affinity relative to dexamethasone (100)

their binding affinity to glucocorticoid receptors in lung tissues and in terms of their ability to induce cutaneous vasoconstriction. For example, FP is twice as potent in terms of binding affinity and cutaneous vasoconstrictor test than budesonide and BDP/BMP, while MF is as potent as fluticasone. In vitro anti-inflammatory assays such as the repression of the activity of pro-inflammatory transcription factor NF-KB in A549 lung epithelial cells show the equipotency of BDP, ciclesonide and budesonide, while FP and MF are 5- to 10-fold more potent [98].

Factors other than in-vitro potency need to be taken into account when it comes to assessing ICS in clinical practice. Efficacy of ICS is affected by the delivery device, or by the mechanism of action (e.g. prodrugs such as BDP and ciclesonide). BDP and budesonide are nearly equiactive, whereas fluticasone is equally active at half the microgram dosage. Mometasone is nearly equipotent with FP, and ciclesonide probably falls somewhere between the potency of BDP and fluticasone. The overall effect of ICS is also dependent on its deposition in the airways. A large proportion of the dose $(60-90 \%$ depending on the inhaler device used and on the inhalation technique) is deposited in the upper airways (mouth, larynx and pharynx) and enters the gastrointestinal tract. The level of systemic absorption of the corticosteroid determines the systemic bioavailability and potential for systemic side effects and is dependent upon the efficiency of absorption of the dose deposited in the lower airways (direct absorption into systemic circulation) and upon the efficiency of first-pass liver metabolism of the portion absorbed from the gastrointestinal tract.

Most of the drug absorbed through the gastrointestinal tract undergoes first-pass metabolism, with maximum breakdown of up to $99 \%$ for fluticasone, compared to $20 \%$ for prednisolone [99]. The remaining bioavailability is dependent on the absorption through the lower respiratory tract, and if fluticasone and budesonide undergo first-pass metabolism in the liver, then their absorption though the lower airways determines their bioavailability. The oral bioavailability of ICS has been reduced with newer ICS. Values for BDP and budesonide are quoted as 41 and $11 \%$ respectively, and those for the newer ones such as FP, ciclesonide and MF are less than 1\% [100].

Another property of ICS regarding systemic availability is its retention in the lungs dependent on lipophilicity. For example, FP is more lipophilic than budesonide, and this increases the affinity of FP for lung tissue, increasing the retention time of FP in the lung. On the other hand, budesonide forms highly lipophilic fatty acid ester conjugation in the lung, which can serve as a depot from which the active moiety can be regenerated. These are not absorbed from the lung into the systemic circulation and are not active. The more lipophilic the ICS, the more slowly it is released into and from the lung lipid layer and the longer the latency between inhalation and its appearance in
Table 2 Equipotent daily doses of inhaled corticosteroids for adults

\begin{tabular}{lccc}
\hline Inhaled corticosteroid & Low daily dose $(\mu \mathrm{g})$ & Medium daily dose $(\mu \mathrm{g})$ & High daily dose $(\mu \mathrm{g})$ \\
\hline Beclomethasone propionate & $200-500$ & $>500-1,000$ & $>1,000-2,000$ \\
Budesonide & $200-400$ & $>400-800$ & $>800-1,600$ \\
Ciclesonide & $80-160$ & $>160-320$ & $>320-1,280$ \\
Flunisolide & $500-1,000$ & $>1,000-2,000$ & $>2,000$ \\
Fluticasone propionate & $100-250$ & $>250-500$ & $>500-1,000$ \\
Mometasone furoate & $200-400$ & $>400-800$ & $>800-1,200$ \\
Triamcinolone acetonide & $400-1,000$ & $>1,000-2,000$ & $>2,000$ \\
\hline
\end{tabular}


the plasma. Thus, the rate of dissolution of budesonide in human bronchial fluid is quoted as only $6 \mathrm{~min}$ while it is over $8 \mathrm{~h}$ for fluticasone [99].

Some topical steroids are only activated in the lungs. BDP is metabolised in the airways to BMP, which is a more active steroid than BDP, while budesonide is stable within the airways. Fluticasone furoate, which is currently being developed, has a binding affinity to the human lung glucocorticoid receptor reported to be the highest of all topical CS together with the most pronounced retention in lung tissue [101], properties that may contribute to a prolonged and potent effect in the lungs.

Ciclesonide is a prodrug which is converted into an active moiety in the airways and has a high binding to plasma proteins; it has a pharmacokinetic profile that is associated with a lesser risk of systemic and local side effects. Absorption of ICS, particularly of FP, from the lungs is higher in normal non-asthmatic individuals than in asthmatics with airflow obstruction, probably due to the reduced penetration of aerosols in an obstructed airway [102-104]. This differential absorption between normal and asthmatic individuals appears to be less marked for budesonide and ciclesonide $[103,104]$. Another interesting property of ciclesonide is its very high protein binding to plasma proteins of $99 \%$, similar to MF (98-99\%) and higher than FP (90\%) and budesonide $(88 \%)$. This property allows the ICS to be kept in the blood stream preventing its diffusion into tissues, hence the propensity for causing systemic side effects.

\section{Dose-response relationships}

The dose ranges of various ICS in clinical use are shown in Table 2, and the dose range used to treat an asthmatic patient may be determined by the severity of the disease. All ICS demonstrate a dose-response relationship for efficacy measures for asthma, however, most of the benefit of ICS may be obtained in the low to moderate dose range of each ICS [105]. In some patients, higher doses of ICS may lead to further improvement in asthma control, but at the expense of a greater increase in the potential of side effects. For fluticasone propionate, there were no statistically significant differences between 400-500 and 8001,000 $\mu \mathrm{g}$, and between 50-100 and 800-1,000 $\mu \mathrm{g}$, but 800-1,000 $\mu \mathrm{g}$ daily favoured a greater improvement in $\mathrm{FEV}_{1}$ and symptoms compared to the $200 \mu \mathrm{g}$, although the gain was relatively small [106]. However, very high doses of FP may allow for a reduction in maintenance oral prednisolone in some patients with severe asthma. In terms of prevention of excerbations, the dose-response of ICS in COPD is unclear. It appears that as far as response to symptoms, there is little difference in effect between $500 \mu \mathrm{g}$ and $1,000 \mu \mathrm{g}$ per day dosage $[107,108]$, but there is only one study on the effect of Seretide on exacerbations using a $1,000 \mu \mathrm{g}$ daily dose [109]. The dose-response effect on reduction of exacerbations in COPD needs to be clarified.

\section{Effects of corticosteroids on asthma control}

Control of asthma may be obtained in most asthmatics with inhaled glucocorticoids [110, 111] with improvement in asthma symptoms, in lung function and in a reduction in exacerbations of disease. This applies throughout the severity spectrum of asthma.

\section{Mild persistent asthma}

Recent studies have focused on the use of ICS particularly at the early and at the moderate-to-severe stages of the disease. The early intervention of mild persistent asthma at the time of diagnosis has been conclusively examined in the START study of 7,241 patients aged 5-66 years in 32 countries who had less than 2 years of mild intermittent asthma and who had not been previously treated with corticosteroids [112]. Patients treated with low-dose budesonide had fewer courses of systemic corticosteroids and more symptom-free days than those on placebo. Postbronchodilator $\mathrm{FEV}_{1}$ improved significantly by $1.48 \%$ after 1 year and by $0.88 \%$ after 3 years. In the first year of the START trial, $34 \%$ of asthmatics on placebo needed additional treatment with ICS and $4 \%$ had a severe exacerbation. In those treated with ICS, only $20 \%$ needed additional ICS and $2 \%$ had a severe exacerbation. During the third year, $50 \%$ of patients on placebo were being treated with ICS and $6 \%$ had a severe exacerbation; correspondingly, in the budesonide arm, 30\% were being given additional ICS and 3\% had a severe exacerbation. There were small but significant improvements in both prebronchodilator and post-bronchodilator $\mathrm{FEV}_{1}$ at the end of 3 years. Thus, this study indicated benefits of ICS even in the mildest of asthma patients.

In the Childhood Asthma Management Plan (CAMP) study, 1,041 children aged 5-12 years with mild-tomoderate asthma were studied and randomly allocated to budesonide (200 $\mu \mathrm{g} /$ day), nedocromil sodium ( $8 \mathrm{mg}$ ) or placebo twice daily for 4-6 years. The active treatments did not change the primary outcome of change in $\mathrm{FEV}_{1}$ after bronchodilator. However, children who received budesonide had a significantly smaller decline in $\mathrm{FEV}_{1} / \mathrm{FVC}$ ratio and improved airway responsiveness to methacholine, fewer hospital admissions, greater reduction in the need for rescue medication, and fewer courses of prednisolone compared to nedocromil [113].

In a study of mild persistent asthma, budesonide alone (200 $\mu \mathrm{g} /$ day) reduced the rate of severe asthma exacer- 
bations from 0.77 per patient per year to 0.29 per patient per year, with improvement in days with asthma symptoms and nights with nocturnal symptoms [114]. In this study, the addition of formoterol to budesonide did not confer any additional benefit in this group with mild persistent asthma.

Because the use of ICS for long periods of time is not a popular option chosen by asthma patients, likely because of unreasonable fear of CS adverse effects and poor compliance with inhaled therapies, other possibilities have been looked into such as the use of oral leukotriene receptor antagonist (LTRA). However, LTRA do not provide as good a benefit as low-dose inhaled CS therapy [115, 116] although they remain an alternative therapy, particularly in pediatric patients. One study indicated that the intermittent use of ICS combined with a short-acting $\beta$-agonist (SABA) as needed was as effective as the regular use of ICS twice daily with SABA as needed [117]. This is an interesting concept that could be considered further. In addition, the use of intermittent courses of oral corticosteroids to treat exacerbations without any maintenance treatment appears to be as effective as using ICS regularly [118], however, the size of cohort used was probably not big enough to show any differential effect. Another issue with the response of ICS is that at least the bronchodilator response as measured by $\mathrm{FEV}_{1}$ is not uniform across a population of patients with mild to moderate asthma, and a percentage of patients do not respond to ICS [116, 119]. In the study of Martin et al., $46 \%$ of patients with mild to moderate asthma did not respond to low-dose ICS defined as an $\mathrm{FEV}_{1}$ response of less than $5 \%$ of baseline, and the non-responders were associated with a lesser bronchodilator response to salbutamol but without any greater inflammatory index as measured by sputum eosinophils or exhaled nitric oxide levels [119]. Whether this population is more responsive to other treatments such as LTRA is not known.

The other issue is the use of ICS in patients with mild-tomoderate asthma who continue to smoke. The therapeutic response of these patients to ICS is attenuated [120, 121], and whether they should be treated with higher doses of ICS, or with combination therapy of ICS and LABA or LTRA is unclear.

\section{Moderate persistent asthma}

Moderate persistent asthmatics are those patients whose asthma is inadequately controlled on low-dose ICS of $<500$ ug BDP or equivalent ICS. The additional benefits of adding a LABA to ICS compared to increasing the dose of ICS alone in this group include enhanced effects on lungfunction parameters, exacerbation rates and a decrease in the use of rescue-inhaled rapid-acting $\beta_{2}$ agonists. These benefits are seen in all types of asthma from moderate to severe and resulted in similar clinical control at a lower dose of ICS [74]. Indeed, even a single dose of combination formoterol/budesonide gave a greater protection against allergen-induced late asthmatic response and bronchial hyperresponsiveness than either component alone [122]. In a recent meta-analysis, the addition of a LABA to ICS lowered exacerbation rates by $\sim 14 \%$ compared to that observed when ICS doses were doubled [123], resulted in fewer withdrawals from clinical trials and, apart from increased rates of tremor, was safe [124]. The current recommendation is to add LABA to ICS as supported by studies that show no further benefit of doubling the low dose of ICS and the benefit of adding LABA to low-dose ICS. The benefits of combination therapy therefore include a reduction in the rate of asthma exacerbations and prevention of exacerbations with improvement in most indicators of asthma control [114, 125-128]. In the FACET study, a four-fold increase in the dose of ICS (budesonide $200 \mu \mathrm{g} /$ day to $800 \mu \mathrm{g} /$ day) improved all asthma outcomes; addition of LABA to $800 \mu \mathrm{g}$ /day budesonide provided the greatest benefit, with a maximum four-fold reduction in exacerbation rate compared to the budesonide $200 \mu \mathrm{g} /$ day treatment arm [129].

In the GOAL study, in a group of asthmatics with a wide range of severity, three groups of patients were identified at entry taking no ICS (steroid-naïve), low-dose or moderatedose ICS with not-well controlled asthma [128]. The patients were allocated to either increasing doses of the ICS flixotide alone or with the LABA salmeterol for 1 year. Total asthma control, defined as patients with no symptoms, normal lung function and no limitation of activities, could be achieved in $<50 \%$ of the population and $<30 \%$ of patients already taking moderate doses of ICS at randomization. Well-controlled asthma with only occasional symptoms was reported in $78 \%$ of patients not receiving ICS before entry to study and in $62 \%$ of these already on moderate doses of ICS. Combination of ICS and LABA was significantly better than ICS alone. Thus, with individualized incremental treatment, comprehensive asthma control can be achieved in the majority of patients.

Short-term (12-week) studies have shown that these improvements in clinical parameters were associated with reduced tissue and sputum inflammatory markers, however, this was not seen in biopsies following 16 weeks of formoterol/budesonide treatment [130]. Moreover, improvements in lung function, symptom scores and bronchial hyper-responsiveness following inhaled fluticasone $(500 \mu \mathrm{g}$ daily) in combination with salmeterol (100 $\mu \mathrm{g}$ daily) treatment were associated with changes in sputum $\alpha 2$ macroglobulin and albumin rather than in sputum cell counts [131] and also reduced serum IL-5 and peripheral blood eosinophil numbers [132].

O'Byrne and colleagues examined in a population of asthmatics with moderate to severe disease the use of the 
combination formoterol/budesonide (Symbicort) as both maintenance and reliever medication (Symbicort maintenance and relief therapy, SMART) [125]. This was associated with a $54 \%$ reduction in the annual rate of severe exacerbations compared with ICS alone and a $60 \%$ reduction in the mean daily dose of ICS compared with ICS mono-therapy. Similar benefits were obtained when formoterol and budesonide combination was used as maintenance and reliever medication when compared to the use of this combination as maintenance, with either as-needed terbutaline or as-needed formoterol [133].

These studies also suggest that at least part of the benefit of this approach is due to increasing the glucocorticoid dose in patients at the onset of symptoms. However, this study did not address whether control could be maintained if treatment was reduced. More recent work has suggested that when treatment reduction is indicated it is best to reduce the glucocorticoid dose rather than remove the LABA [134]. Currently, overall, there is no clear clinical evidence that suggests that one drug combination is better than the other in the short term [135] although differences in the device may be important in lung deposition in asthmatic patients with poor inspiratory flow [136] and treatment regimes may benefit some patients over others $[125,133,137,138]$. Indeed, the recent demonstration that the combination of formoterol/beclomethasone in a single inhaler is equivalent to formoterol/budesonide and salmeterol/ fluticasone with respect to asthma control, rates of asthma exacerbations and frequency of adverse events emphasises this point [139-141].

\section{Effects of inhaled corticosteroids in COPD}

ICS are now widely prescribed for COPD and are often used as frequently in patients with COPD as in those with asthma. However, long-term clinical trials with high doses of ICS in the treatment of stable COPD have been disappointing, as they do not appear to arrest the progressive decline in lung function even when treatment was started before the disease became symptomatic. Regular long-term treatment of stable COPD patients with ICS has only small and inconsistent effects on symptoms, quality of life or exacerbations. At the same time this treatment can produce systemic adverse effects, including skin bruising, adrenal suppression or loss of bone density [142-144]. Not surprisingly the inflammation in COPD is scarcely suppressed by inhaled or oral glucocorticoids, even at high doses [66, 145, 146].

\section{Effect of ICS alone}

The long-term effects of ICS have been studied over the last 15 years. First, because of its anti-inflammatory effect, it was hoped that long-term ICS could alter the natural course of COPD such as the long-term decline in $\mathrm{FEV}_{1}$. However, no significant effects of ICS alone on slope has been shown [142, 147-149]. However, in two subsequent meta-analyses published, one concluded that ICS reduced $\mathrm{FEV}_{1}$ decline by a small statistical mean rate of $7.7 \mathrm{ml} /$ year [150], while another meta-analysis showed a non-significant $5.0 \mathrm{ml} /$ year reduction [151]. However, in the 3-year TORCH study, a multicentre double-blind placebo-controlled randomised clinical trial involving 6,112 patients with COPD (mean post-bronchodilator FEV1 of 44\%), fluticasone showed a significant improvement in $\mathrm{FEV}_{1}$ decline of $-42 \mathrm{ml} /$ year compared to placebo of $-55 \mathrm{ml} /$ year [152]. This effect was not significantly different from that of salmeterol or of the combination of salmeterol and fluticasone together. This definite effect of treatments on lung-function decline was likely to have been observed because of the adequate size of the COPD cohort in this study.

These studies show that ICS can induce a small degree of sustained improvement in baseline $\mathrm{FEV}_{1}$, which averages 50 to $75 \mathrm{ml}$, and which occurs fairly rapidly after ICS initiation [142, 148, 153, 154]. Mean improvements in SGRQ of between 1 and 3 units are reported [109, 142, $153,155]$. In one of the largest studies, the improvement observed with fluticasone over a 3-year period was -2.0 units with $95 \%$ CI of -1.0 to -2.9 units compared to placebo arm [154]. These changes were within the 4-unit change in SGRQ which is not considered clinically important. Small improvements in cough and dyspnea have also been reported [107, 108, 156], which are probably reflected in the improvements in SGRQ. Similar results have been obtained with mometasone furoate $(800 \mu \mathrm{g} /$ day $)$ taken either once daily or twice daily [157].

In a systematic analysis of 10 trials that included 3,724 patients [158], a relative reduction of $22 \%$ in the number of subjects who experienced one or more exacerbations was found. In the TORCH study, fluticasone compared to placebo reduced moderate to severe exacerbations by $18 \%$, but with no significant effect on hospitalisation due to exacerbations of COPD [159]. Most studies indicate that the greatest benefit in terms of exacerbations appears to be in those with the most advanced COPD, as measured by the baseline $\mathrm{FEV}_{1}$ [160-162]. Withdrawal studies also led to an increase in the rate of mild exacerbations and symptoms, and a decrease in health status, with decreases in $\mathrm{FEV}_{1}$ [161, 163, 164].

Observational studies of COPD databases have suggested that inhaled corticosteroids either alone or in combination with long-acting $\beta$-agonists may reduce mortality rates in COPD [165-167]. Another study did not show this advantage when data were analysed based on an according-to-treatment approach, and the survival benefit of the previous studies was attributed to bias from unaccount- 
ed immortal time in the cohort design and analysis [168]. In a review of seven randomised controlled trials comparing ICS with placebo that lasted 12 months or longer involving 5,058 patients, a significant $27 \%$ relative reduction in allcause mortality was found, but because the overall rate of mortality was only $4 \%$, the absolute risk reduction worked out to be $\sim 1 \%$ [169]. This data may be biased because of incomplete ascertainment of mortality in those patients who did not complete the study. However, in the TORCH study, there was no effect of ICS alone on mortality compared with placebo (HR 1.06; 95\% CI 0.89-1.27).

\section{Combination of ICS with LABA}

The ICS and LABA combination is now widely recommended for prescription for COPD using combination formulations such as salmeterol and fluticasone or formoterol and budesonide because, in general, the addition of LABA to ICS provides additional benefits. An additive bronchodilator response from ICS is observed, and most studies show a mean improvement in $\mathrm{FEV}_{1}$ of 50-75 $\mathrm{ml}$ [107-109, 142, 154, $156,170]$. The same studies also demonstrate an additive effect on the SGRQ score, with an average increase below the 4-unit change that is regarded as clinically significant improvement [171]. The TORCH study is likely to be the best one to demonstrate the effect of the combination of LABA and ICS in reducing the annualised COPD exacerbation rate, which was significantly lower than for ICS alone [154]. In the TORCH study, the combination of ICS and LABA reduced the rate of decline in $\mathrm{FEV}_{1}$ in patients with moderate-to-severe COPD by $16 \mathrm{ml} /$ year compared to placebo. This improvement was also observed in the LABA-only and in the ICS-only group [152].

Combination of LABA with ICS reduced the number of exacerbations over a 1-year period, while ICS alone had no effect $[153,170]$. The TORCH study found that there was a $25 \%$ reduction in exacerbations with a combination therapy compared with placebo, which was significantly better than ICS alone [154]. This study also reported that the combination of salmeterol and fluticasone decreased the risk of all-cause mortality over a 3 -year period by $17.5 \%$ compared with placebo at a $P$ value of 0.052 .

\section{Using ICS for treating exacerbations of asthma and COPD}

\section{Asthma exacerbations}

Three randomised placebo-controlled studies have failed to demonstrate a benefit from doubling the dose of ICS to treat exacerbations of asthma [172-174]. On the other hand, high-dose ICS can improve symptoms and lung function during exacerbation to the same extent as a standard course of oral corticosteroids [175-181]. Single high ICS doses, as well as high doses delivered in the emergency room over a 3- to 8-h period also produced improvement in symptoms and/or lung function similar to those achieved by intravenous or oral corticosteroids. Thus, increasing ICS to high doses as an alternative to oral corticosteroids to treat exacerbations is supported by evidence in adults. Studies that used ICS doses equivalent to 2,400-4,000 $\mu \mathrm{g}$ of BDP for 1-2 weeks during mild-to-moderate exacerbations demonstrated improved symptoms and lung function with effects similar to those of oral corticosteroids. It would be reasonable to consider using daily doses of up to $2,000 \mu \mathrm{g}$ of fluticasone or 3,200 $\mu \mathrm{g}$ budesonide or equivalent for $7-$ 14 days [182]. The long-term side effects from this approach are unknown. Oral corticosteroids remain the treatment of choice for severe exacerbations or for exacerbations that do not respond to high-dose ICS.

\section{COPD exacerbations}

Successful use of nebulised budesonide has been reported in the treatment of acute exacerbations of COPD [183]. In this study, nebulised budesonide $(2 \mathrm{mg})$ provided statistically significant improvements in post-bronchodilator $\mathrm{FEV}_{1}$ compared to placebo treatment, and the improvement found was similar to that caused by using prednisolone $30 \mathrm{mg}$ every $12 \mathrm{~h}$. Treatment with nebulised budesonide was safer than that provided by oral prednisolone which increased the prevalence of hyperglycaemic episodes. One of the major limitations with nebulised treatment in acute exacerbations of COPD is the penetration and deposition of aerosol into the small airways; further progress in this area will depend on the development of efficacious methods of aerosol delivery in the face of severe airflow obstruction.

\section{Side effects of ICS}

Local side effects

The major local side effects of ICS include oral candidiasis, hoarseness and dysphonia. Cough is also a potential side effect induced by the inhaler and not dependent on the constituent of the inhaled drug. It can usually be overcome by changing the delivery device (e.g. changing dry powder inhaler to a metered dose inhaler, or adding a spacer device to an MDI). In all studies in COPD, there was greater incidence of candidiasis in the fluticasone only or the combined fluticasone- and salmeterol-treated groups compared to the placebo and salmeterol groups. In the 1-year Tristan study, the frequency of candidiasis in the fluticasone group was $7 \%$, and in the combination group $8 \%$ compared 
to $2 \%$ in both placebo and salmeterol groups [109]. Oral candidiasis can be prevented by gargling, washing with water and then spitting out after using the inhaler. Local antifungal agents may be needed. Hoarseness and dysphonia are caused by the myopathy of the arytenoid muccles caused by the deposition of ICS on the vocal cords; these effects are also dose-related and are more of a problem in those who use their voice a lot. Ciclesonide may cause fewer local side effects since it is not metabolised into active ciclesonide in the upper airways. Use of high-dose ICS is particularly associated with an increased incidence of oral thrush and dysphonia in COPD [160].

\section{Systemic side effects}

These result from the portion of steroids that is absorbed from the bronchial submucosa, as a large portion of ICS absorbed from the gastrointestinal tract is usually metabolised by the liver. The degree of systemic side effects depends on the amount deposited in the lower airways, and this in turn depends on the efficiency of the inhaler device [100]. An ideal corticosteroid that would have minimal potential for systemic side effects should stay in the airways for a sufficient period of time to have its anti-inflammatory actions in the airways (estimated at 2-3 h), and then be metabolised in inactive metabolites before absorption into the systemic circulation. High protein binding in the circulation may also be important, as this would minimise the exposure of tissues to the effects of corticosteroids [100].

Systemic side effects of inhaled steroids may be assessed by surrogate markers such as blood cortisols or serum osteocalcin. A progressive reduction in adrenal function can be observed with increasing doses of ICS over relatively short periods [102, 184, 185]. For example 5 days of treatment with high doses of fluticasone and budesonide caused near-complete reduction of the 24-h plasma cortisol profile [185]. Morning cortisols decreased during fluticasone treatment and during combination therapy, while they increased in the placebo and salmeterol groups, after 52 weeks of treatment, but these changes were small and levels remained within the normal reference values. However, cases of adrenal crises have been reported with ICS; of the 33 patients reported, 28 were children and most were taking doses of ICS within the recommended doses according to UK guidelines at that time. There is potential for ICS to cause adrenal suppression but this is not a common event, and clinicians need always to be aware of this idiosyncratic potentiality $[186,187]$.

Of the randomised prospective studies of the side effects of ICS when compared to placebo, there is about a 2-fold increase in patients reporting easy bruising [148, 149], reduction in growth velocity $[112,113]$ and in bone mineral density [149]. There have been no comparable data for the onset of cataract or fractures because such studies would need longer duration of observation, but case-control and cross-sectional studies have found associations between ICS and cataract [188], glaucoma [189] and bone mineral density measurements [190]. In children, dose-related inhibition of growth has been seen in some short- and intermediate-term studies, but long-term studies have found no detrimental effect on final height. There is some evidence of a small decrease in statural growth during the initial period of ICS therapy, an effect that was more marked at daily doses of $>200 \mu \mathrm{g}$ and did not apply to all treatment regimens. Studies examining final attained adult height found no difference between children treated with ICS and those receiving nonsteroidal therapy [191].

Of more relevance to COPD, an increase in pneumonia has been reported in patients with moderate to severe COPD treated with high-dose ICS [154]. In the TORCH study, patients in all fluticasone treatment arms experienced an excess in the rate of non-fatal pneumonia of $\sim 3$ per 100 per year compared to treatment arms not containing fluticasone. This may be related to the immunosuppressive effect of corticosteroids and the decreased immune responses of advanced COPD patients.

\section{Bone and risk of fractures}

Long-term studies are needed to assess the risk of osteoporosis. Measurements of morning cortisols and of plasma levels of osteocalcin or markers of bone activity indicate that inhaled steroids at doses above $800-1,000 \mu \mathrm{g} / \mathrm{day}$ of BDP or budesonide equivalent may have systemic effects. ICS have minimal systemic effects in most patients when taken at recommended doses and the benefits of ICS therapy outweigh the risks of uncontrolled asthma.

Two studies have now shown a relationship between the doses of ICS taken during a 2- to 3-year period and a reduction in BMD at one or more than one site, after allowing for other factors that affect BMD [143, 192]. In COPD patients, triamcinolone $600 \mu \mathrm{g}$ twice daily was associated with a greater reduction in BMD over 3 years than those allocated to placebo and with a reduction in femoral neck BMD by $2 \%$ over a 4-year period [149]. However, in a similar study with budesonide $(800 \mu \mathrm{g} /$ day $)$, there was no difference observed against placebo [148], perhaps reflecting the differences between triamcinolone and budesonide. In a study of patients aged 20-40 years old with $80 \%$ taking beclomethasone, a relationship between BMD measurements and total life cumulative doses of ICS has been reported [190]. In this study, it was calculated that a patient taking $1,000 \mu \mathrm{g}$ /day ICSs for 14 years would expect a reduction in BMD of one SD over that time as a result of ICS. Another study in postmenopausal women performed cross-sectionally did not show any effect of ICS 
on BMD [193]. Cumulative ICS use was associated with a small decrease in bone mineral accretion in boys but not girls but no increased risk for osteopenia [194]. There are no data as to whether any particular ICS is more likely to be associated with a reduction in BMD.

The risk of hip fracture is associated with the use of ICS (84\% were taking BDP) with an overall odds ratio of 1.19 after adjustment for the use of oral steroids, with a dose response such that for those taking more than 1,600 $\mu \mathrm{g}$ ICS per day, the odds ratio increased to 1.84 [195]. In a Canadian case-control study, there was a dose-response relationship between ICS use and fractures, but there were concurrent contributions by both oral CS exposure and inhaled bronchodilators [196]. In COPD patients, an increase in fracture risk is reported amongst those taking $700 \mu \mathrm{g}$ ICS or more daily [197]. A meta-analysis of 13 studies reported no association between use of ICS and fractures in older adults, although a slight increase in risk was seen in those on high-dose ICS [198].

In all the reported studies, it is difficult to disentangle the potential contribution of confounding factors such as oral steroid use, cigarette smoking, sedentariness and dietary factors. It is likely that at doses under $800 \mu \mathrm{g}$ of BDP daily or equivalent, the risk of reduced BMD or of fracture is probably not increased but above $1,000 \mu \mathrm{g} /$ day, there is an increased risk.

\section{Risks of LABAs}

There has been a growing concern with the use of LABAs in the treatment of asthma particularly with the enhanced risk of death from asthma. This issue was raised following a study to test the safety of the LABA salmeterol. In this trial, patients with asthma who were not otherwise taking a LABA were randomly assigned to a LABA or placebo for 28 weeks with continuation of usual treatments. The trial was prematurely terminated because of adverse outcomes. In this study, the salmeterol-treated group had a 4.37 increased risk for the secondary end-point of asthma-related death [199]. This study has reinforced the generally accepted view that LABAs should not be used as monotherapy for patients with asthma, and that whenever LABAs are introduced for the management of asthma, it should be in combination (or together) with ICS given the therapeutic benefit of the combination therapy with regards to improved lung function and reduction in exacerbation rates. Indeed, LABAs should be added when ICS alone do not provide adequate asthma control. A meta-analysis of controlled trials of the use of LABAs - comparing LABA without ICS with non-LABA therapy-for asthma involving 60,954 patients showed that there was a statistically significant rate of 3.63 per 1,000 subjects of the composite end point of asthma-related death, intubation or hospital- isation, whereas this was 0.25 per 1,000 subjects in trials comparing LABAs plus ICS with ICS alone [200]. Although these data are reassuring for the use of combination ICS and LABA, only large prospective studies in relevant cohorts of patients with asthma treated according to guidelines will provide the final answer about the real risk of the addition of LABA to ICS therapy.

\section{Future developments in inhaled corticosteroid therapy}

The currently available combination of ICS and LABAs is usually used on a twice-daily basis, although for mild disease a once-daily use may be sufficient. The development of LABAs that have a once-daily usage and of more potent ICS may pave the way for a once-daily combination therapy for the treatment of asthma of a whole range of severities. More potent ICS may be developed by finding molecules that have even higher affinity for the glucocorticoid receptor with a greater retention in lung tissue, such as the development of fluticasone furoate [101]. A oncedaily ICS or a combination of ICS and LABA may lead to improved patient compliance, but it would remain to be seen whether this could also be used as rescue medication in the same way as the combination of formoterol and budesonide, a twice-daily preparation, can be used.

Another way of increasing potency of ICS would be to adapt the side chains of current ICS. For example, the addition of an NO-donating group to prednisolone (Compound NCX1015) or budesonide (Compound NCX1020) has resulted in improved corticosteroid efficacy compared to the parent compounds in animal models resulting from the donation of the nitric oxide moiety to specific residues within the glucocorticoid receptor ligand-binding domain [201, 202].

Increasing the potency of ICS may be accompanied by an increased risk of side effects [203], due to greater systemic side effects from the systemically absorbed portion from the lungs. Several approaches have been taken to reduce these problems including systemic or local inactivation or administration of an inactive pro-drug that is only converted to active drug in the airways. Ciclesonide is one such recent example [204]; it is esterified only in the lungs to produce the active form des-ciclesonide. There is further scope for introducing even more potent ICS that work by this mechanism of local lung activation. Another approach is based on the concept of dissociated steroids, also called selective glucocorticoid receptor agonists [205]. Many, but not all, of the side effects of corticosteroids are due to the DNA-binding (GRE) effects of the drugs whereas the anti-inflammatory effects may relate predominantly to targeting of pro-inflammatory transcription factors such as NF-kB and AP-1 [7, 206, 207]. The development of dissociated corticosteroids that can interact 
with NF-kB, but not with GREs, thereby preserving therapeutic anti-inflammatory effects with reduced sideeffect profiles has been undertaken by many companies [203]. These dissociated corticosteroids may be just as effective as conventional ICS but may have a better safety profile [205]. One of the problems with conventional corticosteroids is that the steroid backbone can also bind to other nuclear hormone receptors such as MR and PR which also cause side effects. The development of dissociated corticosteroids with a non-steroidal backbone such as AL-438 and ZK 216348 may further improve the therapeutic index of these drugs $[205,208]$ and also extend their duration of action to a once-a-day therapy.

Other nuclear hormone receptors, e.g. LXR, PPAR $\gamma$ and RXR, have distinct anti-inflammatory patterns in murine macrophages [209] which may be complementary to that seen with corticosteroids. Combination of corticosteroids or possibly more promiscuous drugs that bind to two or more of these receptors may result in an enhanced antiinflammatory profile over that seen with current corticosteroids, particularly in patients with severe disease [210]. Several key signalling pathways are involved in the inflammatory response [211, 212] and also in the modulation of corticosteroid responsiveness in asthma and COPD $[11,213-216]$.

A most attractive option is to reverse the cause of corticosteroid insensitivity if molecular causes can be identified. This might be possible for some patients with p38 MAPK, JNK inhibitors and vitamin D3 in the future [6, 91, 217]. Selective activation of HDAC2 can be achieved with theophylline, which restores HDAC2 activity in COPD macrophages back to normal and reverses steroid resistance [218]. The molecular mechanism of action of theophylline in restoring $\mathrm{HDAC} 2$ may be via selective inhibition of $\mathrm{PI} 3 \mathrm{~K} \delta$, which is activated by oxidative stress in COPD patients [219]. Since oxidative stress appears to be an important mechanism in reducing HDAC2 and leads to steroid resistance, antioxidants should also be effective. Unfortunately currently available antioxidants are not very effective and several more potent antioxidants are in clinical development [220].

There may be other partners of ICS than LABAs that may lead to greater efficacy of ICS. Thus, multicombination therapies involving corticosteroids and pathway inhibitors and other nuclear hormone receptor ligands as seen in other therapeutic areas such as rheumatoid arthritis may be introduced [221]. The interactions between ICS and other agents may not increase efficacy by additive mechanisms, but some agents may improve the molecular mechanisms of corticosteroids that may be defective in airways disease. Therefore, ICS therapy may remain central to the treatment of airways diseases but in combination with one or more agents.
Statement of interest K.F.C. has participated in Advisory Board meetings to discuss therapies for airways diseases and had received funding from pharmaceutical companies to take part in clinical trials examining effects of therapies in airways diseases. G.C. has no conflict of interest with regard to this work. I.A. has participated in Advisory Board meetings to discuss drugs used to treat airways diseases and has received grant funding from pharmaceutical companies to study mechanisms of action of such drugs. The writing of this review has not been supported by any pharmaceutical companies.

\section{References}

1. Ito K, Chung KF, Adcock IM (2006) Update on glucocorticoid action and resistance. J Allergy Clin Immunol 117:522-543

2. Weigel NL, Moore NL (2007) Steroid receptor phosphorylation: a key modulator of multiple receptor functions. Mol Endocrinol 21:2311-2319

3. Adcock IM, Barnes PJ (2008) Molecular mechanisms of corticosteroid resistance. Chest 134:394-401

4. Li B, Carey M, Workman JL (2007) The role of chromatin during transcription. Cell 128:707-719

5. So AY, Chaivorapol C, Bolton EC, Li H, Yamamoto KR (2007) Determinants of cell- and gene-specific transcriptional regulation by the glucocorticoid receptor. PLoS Genet 3:e94

6. Xystrakis E, Kusumakar S, Boswell S, Peek E, Urry Z, Richards DF, Adikibi T, Pridgeon C, Dallman M, Loke TK et al (2006) Reversing the defective induction of IL-10-secreting regulatory $\mathrm{T}$ cells in glucocorticoid-resistant asthma patients. J Clin Invest 116:146-155

7. Ito K, Chung KF, Adcock IM (2006) Update on glucocorticoid action and resistance. J Allergy Clin Immunol 117:522-543

8. De BK, Van CK, Meijer OC, Haegeman G (2008) Selective transrepression versus transactivation mechanisms by glucocorticoid receptor modulators in stress and immune systems. Eur J Pharmacol 583:290-302

9. Nie M, Knox AJ, Pang L (2005) Beta2-adrenoceptor agonists, like glucocorticoids, repress eotaxin gene transcription by selective inhibition of histone $\mathrm{H} 4$ acetylation. J Immunol 175:478-486

10. Clark AR, Martins JR, Tchen CR (2008) Role of dual specificity phosphatases in biological responses to glucocorticoids. J Biol Chem 283:25765-25769

11. Bhavsar P, Hew M, Khorasani N, Torrego A, Barnes PJ, Adcock I, Chung KF (2008) Relative corticosteroid insensitivity of alveolar macrophages in severe asthma compared with nonsevere asthma. Thorax 63:784-790

12. Meyer S, Temme C, Wahle E (2004) Messenger RNA turnover in eukaryotes: pathways and enzymes. Crit Rev Biochem Mol Biol 39:197-216

13. Horvath G, Wanner A (2006) Inhaled corticosteroids: effects on the airway vasculature in bronchial asthma. Eur Respir J 27:172-187

14. Norman AW, Mizwicki MT, Norman DP (2004) Steroidhormone rapid actions, membrane receptors and a conformational ensemble model. Nat Rev Drug Discov 3:27-41

15. Croxtall JD, Choudhury Q, Flower RJ (2000) Glucocorticoids act within minutes to inhibit recruitment of signalling factors to activated EGF receptors through a receptor-dependent, transcriptionindependent mechanism. Br J Pharmacol 130:289-298

16. Jeffery PK, Godfrey RW, Adelroth E, Nelson F, Rogers A, Johansson SA (1992) Effects of treatment on airway inflammation and thickening of basement membrane reticular collagen in asthma. A quantitative light and electron microscopic study. Am Rev Respir Dis 145:890-899 
17. Adelroth E, Rosenhall L, Johansson S-A, Linden M, Venge P (1990) Inflammatory cells and eosinophilic activity in asthmatics investigated by bronchoalveolar lavage: the effects of antiasthmatic treatment with budesonide or terbutaline. Am Rev Respir Dis 142:91-99

18. Laitinen LA, Laitinen A, Haahtele T (1992) A comparative study of the effects of an inhaled corticosteroid, budesemide, and of a $\beta 2$-agonist, terbutaline, on airway inflammation in newly diagnosed asthma. J Allergy Clin Immunol 90:32-42

19. Laursen LC, Taudorf E, Borgeskov S, Kobayasi T, Jensen H, Weeke B (1988) Fiberoptic bronchoscopy and bronchial mucosal biopsies in asthmatics undergoing long-term high-dose budesonide aerosol treatment. Allergy 43:284-288

20. Djukanovic R, Wilson JW, Britten KM, Wilson SJ, Walls AF, Roche WR, Howarth PH, Holgate ST (1992) The effect of an inhaled corticosteroid on airway inflammation and symptoms in asthma. Am Rev Respir Dis 145:669-674

21. van Rensen EL, Straathof KC, Veselic-Charvat MA, Zwinderman AH, Bel EH, Sterk PJ (1999) Effect of inhaled steroids on airway hyperresponsiveness, sputum eosinophils, and exhaled nitric oxide levels in patients with asthma. Thorax 54:403-408

22. Olivieri D, Chetta A, Del Donno M, Bertorelli G, Casalini A, Pesci A, Testi R, Foresi A (1997) Effect of short-term treatment with low-dose inhaled fluticasone propionate on airway inflammation and remodeling in mild asthma: a placebo-controlled study. Am J Respir Crit Care Med 155:1864-1871

23. Orsida BE, Li X, Hickey B, Thien F, Wilson JW, Walters EH (1999) Vascularity in asthmatic airways: relation to inhaled steroid dose. Thorax 54:289-295

24. Brieva JL, Danta I, Wanner A (2000) Effect of an inhaled glucocorticosteroid on airway mucosal blood flow in mild asthma. Am J Respir Crit Care Med 161:293-296

25. Sont JK, Willems LN, Bel EH, van Krieken JH, Vandenbroucke JP, Sterk PJ (1999) Clinical control and histopathologic outcome of asthma when using airway hyperresponsiveness as an additional guide to long-term treatment. The AMPUL Study Group. Am J Respir Crit Care Med 159:1043-1051

26. Gibson PG, Wong BJ, Hepperle MJ, Kline PA, Girgis-Gabardo A, Guyatt G, Dolovich J, Denburg JA, Ramsdale EH, Hargreave FE (1992) A research method to induce and examine a mild exacerbation of asthma by withdrawal of inhaled corticosteroid. Clin Exp Allergy 22:525-532

27. in't Veen C, Smits HH, Hiemstra PS, Zwinderman AE, Sterk PJ, Bel EH (1999) Lung function and sputum characteristics of patients with severe asthma during an induced exacerbation by double-blind steroid withdrawal. Am J Respir Crit Care Med 160:93-99

28. Barnes PJ (1995) Inhaled glucocorticoids for asthma. N Engl J Med 332:868-875

29. Umland SP, Schleimer RP, Johnston SL (2002) Review of the molecular and cellular mechanisms of action of glucocorticoids for use in asthma. Pulm Pharmacol Ther 15:35-50

30. Schleimer RP, Bochner BS (1994) The effects of glucocorticoids on human eosinophils. J Allergy Clin Immunol 94:1202-1213

31. Schleimer RP (1993) An overview of glucocorticoid antiinflammatory actions. Eur J Clin Pharmacol 45(Suppl 1):S3-S7

32. Peters SP, Naclerio RM, Schleimer RP, MacGlashan DW Jr, Pipkorn U, Lichtenstein LM (1986) The pharmacologic control of mediator release from human basophils and mast cells. Respiration 50(Suppl 2):116-122

33. Djukanovic R, Wilson JW, Britten KM, Wilson SJ, Walls AF, Roche WR, Howarth PH, Holgate ST (1992) Effect of an inhaled corticosteroid on airway inflammation and symptoms in asthma. Am Rev Respir Dis 145:669-674

34. Majori M, Piccoli ML, Bertacco S, Cuomo A, Cantini L, Pesci A (1997) Inhaled beclomethasone dipropionate downregulates CD4 and CD8 T-lymphocyte activation in peripheral blood of patients with asthma. J Allergy Clin Immunol 100:379-382

35. Wilson JW, Djukanovic R, Howarth PH, Holgate ST (1994) Inhaled beclomethasone dipropionate downregulates airway lymphocyte activation in atopic asthma. Am J Respir Crit Care Med 149:86-90

36. Borish L, Mascali JJ, Dishuck J, Beam WR, Martin RJ, Rosenwasser LJ (1992) Detection of alveolar macrophagederived IL-1 beta in asthma. Inhibition with corticosteroids. J Immunol 149:3078-3082

37. Dworski R, Fitzgerald GA, Oates JA, Sheller JR (1994) Effect of oral prednisone on airway inflammatory mediators in atopic asthma. Am J Respir Crit Care Med 149:953-959

38. Wenzel SE, Szefler SJ, Leung DYM, Sloan SI, Rex MD, Martin RJ (1997) Bronchoscopic evaluation of severe asthma: persistent inflammation associated with high dose glucocorticoids. Amer J Respir Crit Care Med 156:737-743

39. Cox G (1995) Glucocorticoid treatment inhibits apoptosis in human neutrophils. Separation of survival and activation outcomes. J Immunol 154:4719-4725

40. Schleimer RP, Freeland HS, Peters SP, Brown KE, Derse CP (1989) An assessment of the effects of glucocorticoids on degranulation, chemotaxis, binding to vascular endothelium and formation of leukotriene B4 by purified human neutrophils. J Pharmacol Exp Ther 250:598-605

41. Kharitonov SA, Yates DH, Chung KF, Barnes PJ (1996) Changes in the dose of inhaled steroid affect exhaled nitric oxide levels in asthmatic patients. Eur Respir J 9:196-201

42. Chung KF, Barnes PJ (1999) Cytokines in asthma. Thorax $54: 825-857$

43. Chung KF (2008) Asthma treatments: effects on the airway smooth muscle. In: Chung KF (ed) Airway smooth muscle in asthma and COPD: biology and pharmacology. John Wiley \& Sons, Chichester, pp 277-302

44. John M, Lim S, Seybold J, Jose P, Robichaud A, O'Connor B, Barnes PJ, Chung KF (1998) Inhaled corticosteroids increase interleukin-10 but reduce macrophage inflammatory protein1alpha, granulocyte-macrophage colony-stimulating factor, and interferon-gamma release from alveolar macrophages in asthma. Am J Respir Crit Care Med 157:256-262

45. Sousa AR, Trigg CJ, Lane SJ, Hawksworth R, Nakhosteen JA, Poston RN, Lee TH (1997) Effect of inhaled glucocorticoids on IL-1 beta and IL-1 receptor antagonist (IL-1 ra) expression in asthmatic bronchial epithelium. Thorax 52:407-410

46. Chung KF (1986) Role played by inflammation in the hyperreactivity of the airways in asthma. Thorax 41:657-662

47. Juniper EF, Kline PA, Vanzieleghem MA, Ramsdale EH, O'Byrne PM, Hargreave FE (1990) Effect of a long-term treatment with an inhaled corticosteroid (budesonide) on airway hyperresponsiveness and clinical asthma in nonsteroiddependent asthma. Am Rev Respir Dis 142:832-836

48. Ward C, Pais M, Bish R, Reid D, Feltis B, Johns D, Walters EH (2002) Airway inflammation, basement membrane thickening and bronchial hyperresponsiveness in asthma. Thorax 57:309-316

49. Vathenen AS, Knox AJ, Wisniewski A, Tattersfield AE (1991) Effect of inhaled budesonide on bronchial reactivity to histamine, exercise and encepnic dry air hyperventilation in patients with asthma. Thorax 46:811-816

50. Barnes PJ (1990) Effect of corticosteroids on airway hyperresponsiveness. Am Rev Respir Dis 141:S70-S76

51. van den Berge M, Kerstjens HA, Meijer RJ, de Reus DM, Koeter GH, Kauffman HF, Postma DS (2001) Corticosteroid-induced improvement in the PC20 of adenosine monophosphate is more closely associated with reduction in airway inflammation than improvement in the PC20 of methacholine. Am J Respir Crit Care Med 164:1127-1132 
52. Bel EH, Timmers MC, Zwinderman AH, Dijkman JH, Sterk PJ (1991) The effect of inhaled corticosteroids on the maximal degree of airway narrowing to methacholine in asthmatic subjects. Am Rev Respir Dis 143:109-113

53. Vathenen AS, Knox AJ, Wisniewski A, Tattersfield AE (1991) Time course of change in bronchial reactivity with an inhaled corticosteroid in asthma. Am Rev Respir Dis 143:1317-1321

54. Haahtela T, Jarvinen M, Kava T, Kiviranta K, Koskinen S, Lehtonen K, Nikander K, Persson T, Selroos O, Sovijarvi A et al (1994) Effects of reducing or discontinuing inhaled budesonide in patients with mild asthma. N Engl J Med 331:700-705

55. Juniper EF, Kline PA, Vanzieleghem MA, Hargreave FE (1991) Reduction of budesonide after a year of increased use: a randomized controlled trial to evaluate whether improvements in airway responsiveness and clinical asthma are maintained. J Allergy Clin Immunol 87:483-489

56. Barnes PJ (2000) Chronic obstructive pulmonary disease. N Engl J Med 343:269-280

57. Rabe KF, Hurd S, Anzueto A, Barnes PJ, Buist SA, Calverley P, Fukuchi Y, Jenkins C, Rodriguez-Roisin R, Van Weel C et al (2007) Global strategy for the diagnosis, management, and prevention of chronic obstructive pulmonary disease: GOLD executive summary. Am J Respir Crit Care Med 176:532-555

58. Hogg JC, Chu F, Utokaparch S, Woods R, Elliott WM, Buzatu L, Cherniack RM, Rogers RM, Sciurba FC, Coxson HO et al (2004) The nature of small-airway obstruction in chronic obstructive pulmonary disease. N Engl J Med 350:2645-2653

59. Saetta M, Turato G, Maestrelli P, Mapp CE, Fabbri LM (2001) Cellular and structural bases of chronic obstructive pulmonary disease. Am. J Respir Crit Care Med 163:1304-1309

60. Chung KF, Adcock IM (2008) Multi-faceted mechanism in COPD: inflammation, immunity and tissue repair and destruction. Eur Respir J 31:1334-1356

61. Gan WQ, Man P, Sin DD (2005) Effects of inhaled corticosteroids on sputum cell counts in stable chronic obstructive pulmonary disease: a systematic review and a meta-analysis. BMC Pulm Med 5:3-3

62. Boorsma M, Lutter R, van de Pol MA, Out TA, Jansen HM, Jonkers RE (2008) Long-term effects of budesonide on inflammatory status in COPD. COPD 5:97-104

63. Chanez P, Vignola AM, O’Shaugnessy T, Enander I, Li D, Jeffery PK, Bousquet J (1997) Corticosteroid reversibility in COPD is related to features of asthma. Am J Respir Crit Care Med 155:1529-1534

64. Brightling CE, Monteiro W, Ward R, Parker D, Morgan MD, Wardlaw AJ, Pavord ID (2000) Sputum eosinophilia and shortterm response to prednisolone in chronic obstructive pulmonary disease: a randomised controlled trial. Lancet 356:1480-1485

65. Hattotuwa KL, Gizycki MJ, Ansari TW, Jeffery PK, Barnes NC (2002) The effects of inhaled fluticasone on airway inflammation in chronic obstructive pulmonary disease: a double-blind, placebo-controlled biopsy study. Am J Respir Crit Care Med 165:1592-1596

66. Gizycki MJ, Hattotuwa KL, Barnes N, Jeffery PK (2002) Effects of fluticasone propionate on inflammatory cells in COPD: an ultrastructural examination of endobronchial biopsy tissue. Thorax 57:799-803

67. Barnes NC, Qiu YS, Pavord ID, Parker D, Davis PA, Zhu J, Johnson M, Thomson NC, Jeffery PK (2006) Antiinflammatory effects of salmeterol/fluticasone propionate in chronic obstructive lung disease. Am J Respir Crit Care Med 173:736-743

68. Sin DD, Man SF, Marciniuk DD, Ford G, Fitzgerald M, Wong E, York E, Mainra RR, Ramesh W, Melenka LS et al (2008) The effects of fluticasone with or without salmeterol on systemic biomarkers of inflammation in chronic obstructive pulmonary disease. Am J Respir Crit Care Med 177:1207-1214
69. Man SF, Sin DD (2005) Effects of corticosteroids on systemic inflammation in chronic obstructive pulmonary disease. Proc Am Thorac Soc 2:78-82

70. Adcock IM, Maneechotesuwan K, Usmani O (2002) Molecular interactions between glucocorticoids and long-acting beta2agonists. J Allergy Clin Immunol 110:S261-S268

71. Usmani OS, Ito $\mathrm{K}$, Maneechotesuwan $\mathrm{K}$, Ito $\mathrm{M}$, Johnson $\mathrm{M}$, Barnes PJ, Adcock IM (2005) Glucocorticoid receptor nuclear translocation in airway cells after inhaled combination therapy. Am J Respir Crit Care Med 172:704-712

72. Roth M, Johnson PR, Rudiger JJ, King GG, Ge Q, Burgess JK, Anderson G, Tamm M, Black JL (2002) Interaction between glucocorticoids and beta2 agonists on bronchial airway smooth muscle cells through synchronised cellular signalling. Lancet 360:1293-1299

73. Chung KF, Adcock IM (2004) Combination therapy of longacting beta2-adrenoceptor agonists and corticosteroids for asthma. Treat Respir Med 3:279-289

74. Sin DD, Man SF (2006) Corticosteroids and adrenoceptor agonists: the compliments for combination therapy in chronic airways diseases. Eur J Pharmacol 533:28-35

75. Moore WC, Bleecker ER, Curran-Everett D, Erzurum SC, Ameredes BT, Bacharier L, Calhoun WJ, Castro M, Chung KF, Clark MP et al (2007) Characterization of the severe asthma phenotype by the National Heart, Lung, and Blood Institute's Severe Asthma Research Program. J Allergy Clin Immunol 119:405-413

76. Bumbacea D, Campbell D, Nguyen L, Carr D, Barnes PJ, Robinson D, Chung KF (2004) Parameters associated with persistent airflow obstruction in chronic severe asthma. Eur Respir J 24:122-128

77. Robinson DS, Campbell DA, Durham SR, Pfeffer J, Barnes PJ, Chung KF (2003) Systematic assessment of difficult-to-treat asthma. Eur Respir J 22:478-483

78. Jatakanon A, Uasuf C, Maziak W, Lim S, Chung KF, Barnes PJ (1999) Neutrophilic inflammation in severe persistent asthma. Am J Respir Crit Care Med 160:1532-1539

79. Wenzel SE, Schwartz LB, Langmack EL, Halliday JL, Trudeau JB, Gibbs RL, Chu HW (1999) Evidence that severe asthma can be divided pathologically into two inflammatory subtypes with distinct physiologic and clinical characteristics. Am J Respir Crit Care Med 160:1001-1008

80. Benayoun L, Druilhe A, Dombret MC, Aubier M, Pretolani M (2003) Airway structural alterations selectively associated with severe asthma. Am J Respir Crit Care Med 167:1360-1368

81. Bourdin A, Neveu D, Vachier I, Paganin F, Godard P, Chanez P (2007) Specificity of basement membrane thickening in severe asthma. J Allergy Clin Immunol 119:1367-1374

82. Cohen L, Xueping E, Tarsi J, Ramkumar T, Horiuchi TK, Cochran R, DeMartino S, Schechtman KB, Hussain I, Holtzman $\mathrm{MJ}$ et al (2007) Epithelial cell proliferation contributes to airway remodeling in severe asthma. Am J Respir Crit Care Med 176:138-145

83. Hew M, Bhavsar P, Torrego A, Meah S, Khorasani N, Barnes PJ, Adcock I, Fan CK (2006) Relative corticosteroid insensitivity of peripheral blood mononuclear cells in severe asthma. Am J Respir Crit Care Med 174:134-141

84. Culpitt SV, Rogers DF, Shah P, De Matos C, Russell REK, Donnelly LE, Barnes PJ (2003) Impaired inhibition by dexamethasone of cytokine release by alveolar macrophages from patients with chronic obstructive pulmonary disease. Am J Respir Crit Care Med 167:24-31

85. Ito $\mathrm{K}$, Ito $\mathrm{M}$, Elliott WM, Cosio B, Caramori G, Kon OM, Barczyk A, Hayashi S, Adcock IM, Hogg JC et al (2005) Decreased histone deacetylase activity in chronic obstructive pulmonary disease. N Engl J Med 352:1967-1976 
86. Marban C, Suzanne S, Dequiedt F, de Walque S, Redel L, Van Lint C, Aunis D, Rohr O (2007) Recruitment of chromatinmodifying enzymes by CTIP2 promotes HIV-1 transcriptional silencing. EMBO J 26:412-423

87. Szulakowski P, Crowther AJ, Jimenez LA, Donaldson K, Mayer R, Leonard TB, MacNee W, Drost EM (2006) The effect of smoking on the transcriptional regulation of lung inflammation in patients with chronic obstructive pulmonary disease. Am J Respir Crit Care Med 174:41-50

88. Ito K, Lim S, Caramori G, Cosio B, Chung KF, Adcock IM, Barnes PJ (2002) A molecular mechanism of action of theophylline: induction of histone deacetylase activity to decrease inflammatory gene expression. Proc Natl Acad Sci USA 99:8921-8926

89. Ito K, Yamamura S, Essilfie-Quaye S, Cosio B, Ito M, Barnes PJ, Adcock IM (2006) Histone deacetylase 2-mediated deacetylation of the glucocorticoid receptor enables NF-kappaB suppression. J Exp Med 203:7-13

90. Leung DY, Martin RJ, Szefler SJ, Sher ER, Ying S, Kay AB, Hamid Q (1995) Dysregulation of interleukin 4, interleukin 5, and interferon gamma gene expression in steroid-resistant asthma. J Exp Med 181:33-40

91. Irusen E, Matthews JG, Takahashi A, Barnes PJ, Chung KF, Adcock IM (2002) p38 Mitogen-activated protein kinase-induced glucocorticoid receptor phosphorylation reduces its activity: role in steroid-insensitive asthma. J Allergy Clin Immunol 109:649-657

92. Webster JC, Oakley RH, Jewell CM, Cidlowski JA (2001) Proinflammatory cytokines regulate human glucocorticoid receptor gene expression and lead to the accumulation of the dominant negative beta isoform: a mechanism for the generation of glucocorticoid resistance. Proc Natl Acad Sci USA 98:6865-6870

93. Goleva E, Li LB, Eves PT, Strand MJ, Martin RJ, Leung DY (2006) Increased glucocorticoid receptor beta alters steroid response in glucocorticoid-insensitive asthma. Am J Respir Crit Care Med 173:607-616

94. Lane SJ, Adcock IM, Richards D, Hawrylowicz C, Barnes PJ, Lee TH (1998) Corticosteroid-resistant bronchial asthma is associated with increased c-fos expression in monocytes and $\mathrm{T}$ lymphocytes. J Clin Invest 102:2156-2164

95. Barnes PJ, Ito K, Adcock IM (2004) Corticosteroid resistance in chronic obstructive pulmonary disease: inactivation of histone deacetylase. Lancet 363:731-733

96. Ito K, Yamamura S, Essilfie-Quaye S, Cosio B, Ito M, Barnes PJ, Adcock IM (2006) Histone deacetylase 2-mediated deacetylation of the glucocorticoid receptor enables NF-kappaB suppression. J Exp Med 203:7-13

97. Hawrylowicz CM (2005) Regulatory T cells and IL-10 in allergic inflammation. J Exp Med 202:1459-1463

98. Biggadike K, Uings I, Farrow SN (2004) Designing corticosteroid drugs for pulmonary selectivity. Proc Am Thorac Soc 1:352-355

99. Johnson M (1996) Pharmacodynamics and pharmacokinetics of inhaled glucocorticoids. J Allergy Clin Immunol 97:169-176

100. Winkler J, Hochhaus G, Derendorf H (2004) How the lung handles drugs: pharmacokinetics and pharmacodynamics of inhaled corticosteroids. Proc Am Thorac Soc 1:356-363

101. Valotis A, Hogger P (2007) Human receptor kinetics and lung tissue retention of the enhanced-affinity glucocorticoid fluticasone furoate. Respir Res 8:54

102. Harrison TW, Wisniewski A, Honour J, Tattersfield AE (2001) Comparison of the systemic effects of fluticasone propionate and budesonide given by dry powder inhaler in healthy and asthmatic subjects. Thorax 56:186-191

103. Harrison TW, Tattersfield AE (2003) Plasma concentrations of fluticasone propionate and budesonide following inhalation from dry powder inhalers by healthy and asthmatic subjects. Thorax $58: 258-260$
104. Harrison TW (2001) Systemic availability of inhaled budesonide and fluticasone propionate: healthy versus asthmatic lungs. BioDrugs 15:405-411

105. Adams NP, Jones PW (2006) The dose-response characteristics of inhaled corticosteroids when used to treat asthma: an overview of Cochrane systematic reviews. Respir Med 100:1297-1306

106. Adams NP, Bestall JC, Jones P, Lasserson TJ, Griffiths B, Cates CJ (2008) Fluticasone at different doses for chronic asthma in adults and children. Cochrane Database Syst Rev CD003534

107. Mahler DA, Wire P, Horstman D, Chang CN, Yates J, Fischer T, Shah T (2002) Effectiveness of fluticasone propionate and salmeterol combination delivered via the Diskus device in the treatment of chronic obstructive pulmonary disease. Am J Respir Crit Care Med 166:1084-1091

108. Hanania NA, Darken P, Horstman D, Reisner C, Lee B, Davis S, Shah T (2003) The efficacy and safety of fluticasone propionate (250 microg)/salmeterol (50 microg) combined in the Diskus inhaler for the treatment of COPD. Chest 124:834-843

109. Calverley P, Pauwels R, Vestbo J, Jones P, Pride N, Gulsvik A, Anderson J, Maden C (2003) Combined salmeterol and fluticasone in the treatment of chronic obstructive pulmonary disease: a randomised controlled trial. Lancet 361:449-456

110. Salmeron S, Guerin JC, Godard P, Renon D, Henry-Amar M, Duroux P, Taytard A (1989) High doses of inhaled corticosteroids in unstable chronic asthma. A multicenter, double-blind, placebo-controlled study. Am Rev Respir Dis 140:167-171

111. Haahtela T, Jarvinen M, Kava T, Kiviranta K, Koskinen S, Lehtonen K, Nikander K, Persson T, Reinikainen K, Selroos O et al (1991) Comparison of a beta 2-agonist, terbutaline, with an inhaled corticosteroid, budesonide, in newly detected asthma [see comments]. N Engl J Med 325:388-392

112. Pauwels RA, Pedersen S, Busse WW, Tan WC, Chen YZ, Ohlsson SV, Ullman A, Lamm CJ, O'Byrne PM (2003) Early intervention with budesonide in mild persistent asthma: a randomised, double-blind trial. Lancet 361:1071-1076

113. (2000) Long-term effects of budesonide or nedocromil in children with asthma. The Childhood Asthma Management Program Research Group. N Engl J Med 343:1054-1063

114. O'Byrne PM, Barnes PJ, Rodriguez-Roisin R, Runnerstrom E, Sandstrom T, Svensson K, Tattersfield A (2001) Low dose inhaled budesonide and formoterol in mild persistent asthma: the OPTIMA randomized trial. Am J Respir Crit Care Med 164:1392-1397

115. Israel E, Chervinsky PS, Friedman B, van Bavel J, Skalky CS, Ghannam AF, Bird SR, Edelman JM (2002) Effects of montelukast and beclomethasone on airway function and asthma control. J Allergy Clin Immunol 110:847-854

116. Baumgartner RA, Martinez G, Edelman JM, Rodriguez Gomez GG, Bernstein M, Bird S, Angner R, Polis A, Dass SB, Lu S et al (2003) Distribution of therapeutic response in asthma control between oral montelukast and inhaled beclomethasone. Eur Respir J 21:123-128

117. Papi A, Canonica GW, Maestrelli P, Paggiaro P, Olivieri D, Pozzi E, Crimi N, Vignola AM, Morelli P, Nicolini G et al (2007) Rescue use of beclomethasone and albuterol in a single inhaler for mild asthma. N Engl J Med 356:2040-2052

118. Boushey HA, Sorkness CA, King TS, Sullivan SD, Fahy JV, Lazarus SC, Chinchilli VM, Craig TJ, Dimango EA, Deykin A et al (2005) Daily versus as-needed corticosteroids for mild persistent asthma. N Engl J Med 352:1519-1528

119. Martin RJ, Szefler SJ, King TS, Kraft M, Boushey HA, Chinchilli VM, Craig TJ, Dimango EA, Deykin A, Fahy JV et al (2007) The Predicting Response to Inhaled Corticosteroid Efficacy (PRICE) trial. J Allergy Clin Immunol 119:73-80

120. Lazarus SC, Chinchilli VM, Rollings NJ, Boushey HA, Cherniack R, Craig TJ, Deykin A, DiMango E, Fish JE, Ford 
JG et al (2007) Smoking affects response to inhaled corticosteroids or leukotriene receptor antagonists in asthma. Am J Respir Crit Care Med 175:783-790

121. Chalmers GW, MacLeod KJ, Little SA, Thomson LJ, McSharry CP, Thomson NC (2002) Influence of cigarette smoking on inhaled corticosteroid treatment in mild asthma. Thorax 57:226-230

122. Duong M, Gauvreau G, Watson R, Obminski G, Strinich T, Evans M, Howie K, Killian K, O'Byrne PM (2007) The effects of inhaled budesonide and formoterol in combination and alone when given directly after allergen challenge. J Allergy Clin Immunol 119:322-327

123. Sin DD, Man J, Sharpe H, Gan WQ, Man SF (2004) Pharmacological management to reduce exacerbations in adults with asthma: a systematic review and meta-analysis. JAMA 292:367-376

124. Greenstone IR, Ni Chroinin MN, Masse V, Danish A, Magdalinos H, Zhang X, Ducharme FM (2005) Combination of inhaled longacting beta2-agonists and inhaled steroids versus higher dose of inhaled steroids in children and adults with persistent asthma. Cochrane Database Syst Rev CD005533

125. O’Byrne PM, Bisgaard H, Godard PP, Pistolesi M, Palmqvist M, Zhu Y, Ekstrom T, Bateman ED (2005) Budesonide/formoterol combination therapy as both maintenance and reliever medication in asthma. Am J Respir Crit Care Med 171:129-136

126. Woolcock A, Lundback B, Ringdal N, Jacques LA (1996) Comparison of addition of salmeterol to inhaled steroids with doubling of the dose of inhaled steroids. Am J Respir Crit Care Med 153:1481-1488

127. Zetterstrom O, Buhl R, Mellem H, Perpina M, Hedman J, O'Neill S, Ekstrom T (2001) Improved asthma control with budesonide/formoterol in a single inhaler, compared with budesonide alone. Eur Respir J 18:262-268

128. Bateman ED, Boushey HA, Bousquet J, Busse WW, Clark TJ, Pauwels RA, Pedersen SE (2004) Can guideline-defined asthma control be achieved? The Gaining Optimal Asthma ControL study. Am J Respir Crit Care Med 170:836-844

129. Pauwels RA, Lofdahl C, Postma D, Tattersfield A, O'Byrne P, Barnes PJ, Ullman A (1997) Effect of inhaled formoterol and budesonide on exacerbations of asthma. $\mathrm{N}$ Engl J Med 337:1405-1411

130. Overbeek SE, Mulder PG, Baelemans SM, Hoogsteden HC, Prins JB (2005) Formoterol added to low-dose budesonide has no additional antiinflammatory effect in asthmatic patients. Chest 128:1121-1127

131. Koopmans JG, Lutter R, Jansen HM, van der Zee JS (2006) Adding salmeterol to an inhaled corticosteroid: long term effects on bronchial inflammation in asthma. Thorax 61:306-312

132. Koopmans JG, Lutter R, Jansen HM, van der Zee JS (2005) Adding salmeterol to an inhaled corticosteroid reduces allergeninduced serum IL-5 and peripheral blood eosinophils. J Allergy Clin Immunol 116:1007-1013

133. Rabe KF, Atienza T, Magyar P, Larsson P, Jorup C, Lalloo UG (2006) Effect of budesonide in combination with formoterol for reliever therapy in asthma exacerbations: a randomised controlled, double-blind study. Lancet 368:744-753

134. Bateman ED, Jacques L, Goldfrad C, Atienza T, Mihaescu T, Duggan M (2006) Asthma control can be maintained when fluticasone propionate/salmeterol in a single inhaler is stepped down. J Allergy Clin Immunol 117:563-570

135. Lotvall J, Langley S, Woodcock A (2006) Inhaled steroid/longacting beta 2 agonist combination products provide 24 hours improvement in lung function in adult asthmatic patients. Respir Res 7:110

136. Tarsin WY, Pearson SB, Assi KH, Chrystyn H (2006) Emitted dose estimates from Seretide Diskus and Symbicort Turbuhaler following inhalation by severe asthmatics. Int J Pharm 316:131-137
137. Vogelmeier C, D’Urzo A, Pauwels R, Merino JM, Jaspal M, Boutet S, Naya I, Price D (2005) Budesonide/formoterol maintenance and reliever therapy: an effective asthma treatment option? Eur Respir J 26:819-828

138. Fitzgerald JM, Boulet LP, Follows RM (2005) The CONCEPT trial: a 1-year, multicenter, randomized, double-blind, doubledummy comparison of a stable dosing regimen of salmeterol/ fluticasone propionate with an adjustable maintenance dosing regimen of formoterol/budesonide in adults with persistent asthma. Clin Ther 27:393-406

139. Papi A, Paggiaro PL, Nicolini G, Vignola AM, Fabbri LM (2007) Beclomethasone/formoterol versus budesonide/formoterol combination therapy in asthma. Eur Respir J 29:682-689

140. Bousquet J, Boulet LP, Peters MJ, Magnussen H, Quiralte J, Martinez-Aguilar NE, Carlsheimer A (2007) Budesonide/formoterol for maintenance and relief in uncontrolled asthma vs. highdose salmeterol/fluticasone. Respir Med 101:2437-2446

141. Huchon G, Magnussen H, Chuchalin A, Dymek L, Gonod FB, Bousquet J (2009) Lung function and asthma control with beclomethasone and formoterol in a single inhaler. Respir Med 103:41-49

142. Burge PS, Calverley PM, Jones PW, Spencer S, Anderson JA, Maslen TK (2000) Randomised, double blind, placebo controlled study of fluticasone propionate in patients with moderate to severe chronic obstructive pulmonary disease: the ISOLDE trial. Br Med J 320:1297-1303

143. Israel E, Banerjee TR, Fitzmaurice GM, Kotlov TV, LaHive K, LeBoff MS (2001) Effects of inhaled glucocorticoids on bone density in premenopausal women. N Engl J Med 345:941-947

144. Pauwels RA, Buist AS, Calverley PM, Jenkins CR, Hurd SS (2001) Global strategy for the diagnosis, management, and prevention of chronic obstructive pulmonary disease. NHLBI/ WHO Global Initiative for Chronic Obstructive Lung Disease (GOLD) Workshop summary. Am J Respir Crit Care Med 163:1256-1276

145. Culpitt SV, Maziak W, Loukidis S, Nightingale JA, Matthews JL, Barnes PJ (1999) Effect of high dose inhaled steroid on cells, cytokines, and proteases in induced sputum in chronic obstructive pulmonary disease. Am J Respir Crit Care Med 160:16351639

146. Keatings VM, Jatakanon A, Worsdell YM, Barnes PJ (1997) Effects of inhaled and oral glucocorticoids on inflammatory indices in asthma and COPD. Am J Respir Crit Care Med 155:542-548

147. Vestbo J, Sorensen T, Lange P, Brix A, Torre P, Viskum K (1999) Long-term effect of inhaled budesonide in mild and moderate chronic obstructive pulmonary disease: a randomised controlled trial. Lancet 353:1819-1823

148. Pauwels RA, Lofdahl CG, Laitinen LA, Schouten JP, Postma DS, Pride NB, Ohlsson SV (1999) Long-term treatment with inhaled budesonide in persons with mild chronic obstructive pulmonary disease who continue smoking. European Respiratory Society Study on Chronic Obstructive Pulmonary Disease. N Engl J Med 340:1948-1953

149. Lung Health Study Research Group (2000) Effect of inhaled triamcinolone on the decline in pulmonary function in chronic obstructive pulmonary disease. N Engl J Med 343:1902-1909

150. Sutherland ER (2003) Inhaled corticosteroids in chronic obstructive pulmonary disease. Ann Intern Med 139:864-865

151. Highland KB, Strange C, Heffner JE (2003) Long-term effects of inhaled corticosteroids on FEV1 in patients with chronic obstructive pulmonary disease. A meta-analysis. Ann Intern Med 138:969-973

152. Celli BR, Thomas NE, Anderson JA, Ferguson GT, Jenkins CR, Jones PW, Vestbo J, Knobil K, Yates JC, Calverley PM (2008) Effect of pharmacotherapy on rate of decline of lung function in 
chronic obstructive pulmonary disease: results from the TORCH study. Am J Respir Crit Care Med 178:332-338

153. Szafranski W, Cukier A, Ramirez A, Menga G, Sansores R, Nahabedian S, Peterson S, Olsson H (2003) Efficacy and safety of budesonide/formoterol in the management of chronic obstructive pulmonary disease. Eur Respir J 21:74-81

154. Calverley PM, Anderson JA, Celli B, Ferguson GT, Jenkins C, Jones PW, Yates JC, Vestbo J (2007) Salmeterol and fluticasone propionate and survival in chronic obstructive pulmonary disease. N Engl J Med 356:775-789

155. van der Valk P, Monninkhof E, van der Palen J, Zielhuis G, van Herwaarden C (2002) Effect of discontinuation of inhaled corticosteroids in patients with chronic obstructive pulmonary disease: the COPE study. Am J Respir Crit Care Med 166:1358-1363

156. Paggiaro PL, Dahle R, Bakran I, Frith L, Hollingworth K, Efthimiou J (1998) Multicentre randomised placebo-controlled trial of inhaled fluticasone propionate in patients with chronic obstructive pulmonary disease. International COPD Study Group. Lancet 351:773-780

157. Calverley PM, Rennard S, Nelson HS, Karpel JP, Abbate EH, Stryszak P, Staudinger H (2008) One-year treatment with mometasone furoate in chronic obstructive pulmonary disease. Respir Res 9:73

158. Wilt TJ, Niewoehner D, MacDonald R, Kane RL (2007) Management of stable chronic obstructive pulmonary disease: a systematic review for a clinical practice guideline. Ann Intern Med 147:639-653

159. Calverley PM, Sanchez-Toril F, McIvor A, Teichmann P, Bredenbroeker D, Fabbri LM (2007) Effect of 1-year treatment with roflumilast in severe chronic obstructive pulmonary disease. Am J Respir Crit Care Med 176:154-161

160. Sin DD, McAlister FA, Man SF, Anthonisen NR (2003) Contemporary management of chronic obstructive pulmonary disease: scientific review. JAMA 290:2301-2312

161. van der Valk P, Monninkhof E, van der Palen J, Zielhuis G, van Herwaarden C (2002) Effect of discontinuation of inhaled corticosteroids in patients with chronic obstructive pulmonary disease: the COPE study. Am J Respir Crit Care Med 166:1358-1363

162. Jones PW, Willits LR, Burge PS, Calverley PM (2003) Disease severity and the effect of fluticasone propionate on chronic obstructive pulmonary disease exacerbations. Eur Respir J 21:68-73

163. Wouters EF, Postma DS, Fokkens B, Hop WC, Prins J, Kuipers AF, Pasma HR, Hensing CA, Creutzberg EC (2005) Withdrawal of fluticasone propionate from combined salmeterol/fluticasone treatment in patients with COPD causes immediate and sustained disease deterioration: a randomised controlled trial. Thorax 60:480-487

164. O’Brien A, Russo-Magno P, Karki A, Hiranniramol S, Hardin M, Kaszuba M, Sherman C, Rounds S (2001) Effects of withdrawal of inhaled steroids in men with severe irreversible airflow obstruction. Am J Respir Crit Care Med 164:365-371

165. Sin DD, Tu JV (2001) Inhaled corticosteroids and the risk of mortality and readmission in elderly patients with chronic obstructive pulmonary disease. Am J Respir Crit Care Med 164:580-584

166. Soriano JB, Kiri VA, Pride NB, Vestbo J (2003) Inhaled corticosteroids with/without long-acting beta-agonists reduce the risk of rehospitalization and death in COPD patients. Am J Respir Med 2:67-74

167. Soriano JB, Vestbo J, Pride NB, Kiri V, Maden C, Maier WC (2002) Survival in COPD patients after regular use of fluticasone propionate and salmeterol in general practice. Eur Respir J 20:819-825

168. Suissa S (2004) Inhaled steroids and mortality in COPD: bias from unaccounted immortal time. Eur Respir J 23:391-395
169. Sin DD, Man SF (2007) Systemic inflammation and mortality in chronic obstructive pulmonary disease. Can J Physiol Pharmacol 85:141-147

170. Calverley PM, Boonsawat W, Cseke Z, Zhong N, Peterson S, Olsson H (2003) Maintenance therapy with budesonide and formoterol in chronic obstructive pulmonary disease. Eur Respir J 22:912-919

171. Jones PW (1991) Measurement of quality of life in chronic obstructive lung disease. Eur Resp Rev 1:445-453

172. Fitzgerald JM, Becker A, Sears MR, Mink S, Chung K, Lee J (2004) Doubling the dose of budesonide versus maintenance treatment in asthma exacerbations. Thorax 59:550-556

173. Harrison TW, Oborne J, Newton S, Tattersfield AE (2004) Doubling the dose of inhaled corticosteroid to prevent asthma exacerbations: randomised controlled trial. Lancet 363:271-275

174. Rice-McDonald G, Bowler S, Staines G, Mitchell C (2005) Doubling daily inhaled corticosteroid dose is ineffective in mild to moderately severe attacks of asthma in adults. Intern Med J 35:693-698

175. Gibson PG, Saltos N, Fakes K (2001) Acute anti-inflammatory effects of inhaled budesonide in asthma: a randomized controlled trial. Am J Respir Crit Care Med 163:32-36

176. Rodrigo G, Rodrigo C (1998) Inhaled flunisolide for acute severe asthma. Am J Respir Crit Care Med 157:698-703

177. Rodrigo GJ, Rodrigo C (2000) Rapid-onset asthma attack: a prospective cohort study about characteristics and response to emergency department treatment. Chest 118:1547-1552

178. Edmonds ML, Camargo CA Jr, Pollack CV Jr, Rowe BH (2003) Early use of inhaled corticosteroids in the emergency department treatment of acute asthma. Cochrane Database Syst Rev CD002308

179. Di Franco A, Bacci E, Bartoli ML, Cianchetti S, Dente FL, Taccola M, Vagaggini B, Zingoni M, Paggiaro PL (2006) Inhaled fluticasone propionate is effective as well as oral prednisone in reducing sputum eosinophilia during exacerbations of asthma which do not require hospitalization. Pulm Pharmacol Ther 19:353-360

180. Levy ML, Stevenson C, Maslen T (1996) Comparison of short courses of oral prednisolone and fluticasone propionate in the treatment of adults with acute exacerbations of asthma in primary care. Thorax 51:1087-1092

181. Foresi A, Morelli MC, Catena E (2000) Low-dose budesonide with the addition of an increased dose during exacerbations is effective in long-term asthma control. On behalf of the Italian Study Group. Chest 117:440-446

182. Reddel HK, Barnes DJ (2006) Pharmacological strategies for selfmanagement of asthma exacerbations. Eur Respir J 28:182-199

183. Maltais F, Ostinelli J, Bourbeau J, Tonnel AB, Jacquemet N, Haddon J, Rouleau M, Boukhana M, Martinot JB, Duroux P (2002) Comparison of nebulized budesonide and oral prednisolone with placebo in the treatment of acute exacerbations of chronic obstructive pulmonary disease: a randomized controlled trial. Am J Respir Crit Care Med 165:698-703

184. Donnelly R, Williams KM, Baker AB, Badcock CA, Day RO, Seale JP (1997) Effects of budesonide and fluticasone on 24hour plasma cortisol. A dose-response study. Am J Respir Crit Care Med 156:1746-1751

185. Clark DJ, Grove A, Cargill RI, Lipworth BJ (1996) Comparative adrenal suppression with inhaled budesonide and fluticasone propionate in adult asthmatic patients. Thorax 51:262-266

186. Todd GR (2003) Adrenal crisis due to inhaled steroids is underestimated. Arch Dis Child 88:554-555

187. Todd GR, Acerini CL, Ross-Russell R, Zahra S, Warner JT, McCance D (2002) Survey of adrenal crisis associated with inhaled corticosteroids in the United Kingdom. Arch Dis Child $87: 457-461$ 
188. Cumming RG, Mitchell P, Leeder SR (1997) Use of inhaled corticosteroids and the risk of cataracts. N Engl J Med 337:8-14

189. Garbe E, LeLorier J, Boivin JF, Suissa S (1997) Inhaled and nasal glucocorticoids and the risks of ocular hypertension or open-angle glaucoma. JAMA 277:722-727

190. Wong CA, Walsh LJ, Smith CJ, Wisniewski AF, Lewis SA, Hubbard R, Cawte S, Green DJ, Pringle M, Tattersfield AE (2000) Inhaled corticosteroid use and bone-mineral density in patients with asthma. Lancet 355:1399-1403

191. Pedersen S (2006) Clinical safety of inhaled corticosteroids for asthma in children: an update of long-term trials. Drug Saf 29:599-612

192. Tattersfield AE, Town GI, Johnell O, Picado C, Aubier M, Braillon P, Karlstrom R (2001) Bone mineral density in subjects with mild asthma randomised to treatment with inhaled corticosteroids or non-corticosteroid treatment for two years. Thorax $56: 272-278$

193. Elmstahl S, Ekstrom H, Galvard H, Johnell O, Gerhardsson de Verdier M, Norjavaara E (2003) Is there an association between inhaled corticosteroids and bone density in postmenopausal women? J Allergy Clin Immunol 111:91-96

194. Kelly HW, Van Natta ML, Covar RA, Tonascia J, Green RP, Strunk RC (2008) Effect of long-term corticosteroid use on bone mineral density in children: a prospective longitudinal assessment in the childhood Asthma Management Program (CAMP) study. Ped 122:e53-e61

195. van Staa TP, Leufkens HG, Cooper C (2001) Use of inhaled corticosteroids and risk of fractures. J Bone Miner Res 16:581-588

196. Suissa S, Baltzan M, Kremer R, Ernst P (2004) Inhaled and nasal corticosteroid use and the risk of fracture. Am J Respir Crit Care Med 169:83-88

197. Lee TA, Weiss KB, Sullivan SD (2004) Cost-effectiveness of inhaled corticosteroids in chronic obstructive pulmonary disease. Am J Med 117:618-619

198. Etminan M, Sadatsafavi M, Ganjizadeh ZS, Takkouche B, Fitzgerald JM (2008) Inhaled corticosteroids and the risk of fractures in older adults: a systematic review and meta-analysis. Drug Saf 31:409-414

199. Nelson HS, Weiss ST, Bleecker ER, Yancey SW, Dorinsky PM (2006) The Salmeterol Multicenter Asthma Research Trial: a comparison of usual pharmacotherapy for asthma or usual pharmacotherapy plus salmeterol. Chest 129:15-26

200. Kramer JM (2009) Balancing the benefits and risks of inhaled long-acting beta-agonists-the influence of values. N Engl J Med 360:1592-1595

201. Paul-Clark MJ, Roviezzo F, Flower RJ, Cirino G, Soldato PD, Adcock IM, Perretti M (2003) Glucocorticoid receptor nitration leads to enhanced anti-inflammatory effects of novel steroid ligands. J Immunol 171:3245-3252

202. Nevin BJ, Broadley KJ (2004) Comparative effects of inhaled budesonide and the NO-donating budesonide derivative, NCX 1020, against leukocyte influx and airway hyperreactivity following lipopolysaccharide challenge. Pulm Pharmacol Ther 17:219-232

203. Adcock IM, Caramori G, Chung KF (2008) New targets for drug development in asthma. Lancet 372:1073-1087

204. Derendorf H (2007) Pharmacokinetic and pharmacodynamic properties of inhaled ciclesonide. J Clin Pharmacol 47:782-789

205. Schacke H, Berger M, Rehwinkel H, Asadullah K (2007) Selective glucocorticoid receptor agonists (SEGRAs): novel ligands with an improved therapeutic index. Mol Cell Endocrinol 275:109-117
206. Schacke H, Schottelius A, Docke WD, Strehlke P, Jaroch S, Schmees N, Rehwinkel H, Hennekes H, Asadullah K (2004) Dissociation of transactivation from transrepression by a selective glucocorticoid receptor agonist leads to separation of therapeutic effects from side effects. Proc Natl Acad Sci USA 101:227-232

207. Schacke H, Docke WD, Asadullah K (2002) Mechanisms involved in the side effects of glucocorticoids. Pharmacol Ther 96:23-43

208. Miner JN, Ardecky B, Benbatoul K, Griffiths K, Larson CJ, Mais DE, Marschke K, Rosen J, Vajda E, Zhi L et al (2007) Antiinflammatory glucocorticoid receptor ligand with reduced side effects exhibits an altered protein-protein interaction profile. Proc Natl Acad Sci USA 104:19244-19249

209. Ogawa S, Lozach J, Benner C, Pascual G, Tangirala RK, Westin S, Hoffmann A, Subramaniam S, David M, Rosenfeld MG et al (2005) Molecular determinants of crosstalk between nuclear receptors and toll-like receptors. Cell 122:707-721

210. Farrow SN (2008) Nuclear receptors: doubling up in the lung. Curr Opin Pharmacol 8:275-279

211. Renda T, Baraldo S, Pelaia G, Bazzan E, Turato G, Papi A, Maestrelli P, Maselli R, Vatrella A, Fabbri LM et al (2008) Increased activation of p38 MAPK in COPD. Eur Respir J 31:62-69

212. Ito K, Caramori G, Adcock IM (2007) Therapeutic potential of phosphatidylinositol 3-kinase inhibitors in inflammatory respiratory disease. J Pharmacol Exp Ther 321:1-8

213. Adcock IM, Caramori G, Chung KF (2008) New targets for drug development in asthma. Lancet 372:1073-1087

214. Marwick JA, Stevenson CS, Barnes PJ, Ito K, Adcock IM, Kirkham PA (2008) Cigarette smoke reduces steroid sensitivity by reducing glucocorticoid receptor (GR) and GR co-repressor expression. Proc Am Thorac Soc 5:A333

215. Irusen E, Matthews JG, Takahashi A, Barnes PJ, Chung KF, Adcock IM (2002) p38 Mitogen-activated protein kinaseinduced glucocorticoid receptor phosphorylation reduces its activity: role in steroid-insensitive asthma. J Allergy Clin Immunol 109:649-657

216. Kent L, Smyth L, Plumb J, Clayton C, Fox S, Ray D, Farrow S, Singh D (2008) Inhibition of LPS stimulated COPD macrophage inflammatory gene expression by dexamethasone and the p38 MAPK inhibitor SB706504. J Pharmacol Exp Ther. doi:10.1124/ jpet.108.142950

217. Loke TK, Mallett KH, Ratoff J, O’Connor BJ, Ying S, Meng Q, Soh C, Lee TH, Corrigan CJ (2006) Systemic glucocorticoid reduces bronchial mucosal activation of activator protein 1 components in glucocorticoid-sensitive but not glucocorticoidresistant asthmatic patients. J Allergy Clin Immunol 118:368375

218. Cosio BG, Tsaprouni L, Ito K, Jazrawi E, Adcock IM, Barnes PJ (2004) Theophylline restores histone deacetylase activity and steroid responses in COPD macrophages. J Exp Med 200:689695

219. Ahmad T, Barnes PJ, Adcock IM (2008) Overcoming steroid insensitivity in smoking asthmatics. Curr Opin Investig Drugs 9:470-477

220. Rahman I, Adcock IM (2006) Oxidative stress and redox regulation of lung inflammation in COPD. Eur Respir J 28:219-242

221. Rothschild BM (2008) Review: individual DMARDs have similar efficacy for RA, but combination therapy improves response. Evid Based Med 13:76 